\title{
The creatine kinase system and pleiotropic effects of creatine
}

\author{
Theo Wallimann $\cdot$ Malgorzata Tokarska-Schlattner $\cdot$ Uwe Schlattner
}

Received: 10 July 2010/ Accepted: 2 December 2010/Published online: 30 March 2011

(c) The Author(s) 2011. This article is published with open access at Springerlink.com

\begin{abstract}
The pleiotropic effects of creatine $(\mathrm{Cr})$ are based mostly on the functions of the enzyme creatine kinase (CK) and its high-energy product phosphocreatine (PCr). Multidisciplinary studies have established molecular, cellular, organ and somatic functions of the $\mathrm{CK} / \mathrm{PCr}$ system, in particular for cells and tissues with high and intermittent energy fluctuations. These studies include tissue-specific expression and subcellular localization of CK isoforms, high-resolution molecular structures and structure-function relationships, transgenic CK abrogation and reverse genetic approaches. Three energy-related physiological principles emerge, namely that the $\mathrm{CK} / \mathrm{PCr}$ systems functions as (a) an immediately available temporal energy buffer, (b) a spatial energy buffer or intracellular energy transport system (the CK/PCr energy shuttle or circuit) and (c) a metabolic regulator. The $\mathrm{CK} / \mathrm{PCr}$ energy shuttle connects sites of ATP production (glycolysis and mitochondrial oxidative phosphorylation) with subcellular sites of ATP utilization (ATPases). Thus, diffusion limitations of ADP and ATP are overcome by $\mathrm{PCr} / \mathrm{Cr}$ shuttling, as most clearly seen in polar cells such as spermatozoa, retina
\end{abstract}

\footnotetext{
T. Wallimann $(\varangle)$

Institute of Cell Biology, ETH Zurich, Zurich, Switzerland

e-mail: theo.wallimann@cell.biol.ethz.ch

M. Tokarska-Schlattner · U. Schlattner

INSERM U1055 and University Joseph Fourier Grenoble 1, Laboratory of Fundamental and Applied Bioenergetics, BP 53, 38041 Grenoble cedex 9, France

e-mail: malgorzata.tokarska-schlattner@ujf-grenoble.fr

U. Schlattner

e-mail: uwe.schlattner@ujf-grenoble.fr

Present Address:

T. Wallimann

Schürmattstrasse 23, 8962 Bergdietikon, AG, Switzerland
}

photoreceptor cells and sensory hair bundles of the inner ear. The $\mathrm{CK} / \mathrm{PCr}$ system relies on the close exchange of substrates and products between CK isoforms and ATPgenerating or -consuming processes. Mitochondrial CK in the mitochondrial outer compartment, for example, is tightly coupled to ATP export via adenine nucleotide transporter or carrier (ANT) and thus ATP-synthesis and respiratory chain activity, releasing $\mathrm{PCr}$ into the cytosol. This coupling also reduces formation of reactive oxygen species (ROS) and inhibits mitochondrial permeability transition, an early event in apoptosis. Cr itself may also act as a direct and/or indirect anti-oxidant, while $\mathrm{PCr}$ can interact with and protect cellular membranes. Collectively, these factors may well explain the beneficial effects of $\mathrm{Cr}$ supplementation. The stimulating effects of $\mathrm{Cr}$ for muscle and bone growth and maintenance, and especially in neuroprotection, are now recognized and the first clinical studies are underway. Novel socio-economically relevant applications of $\mathrm{Cr}$ supplementation are emerging, e.g. for senior people, intensive care units and dialysis patients, who are notoriously Cr-depleted. Also, Cr will likely be beneficial for the healthy development of premature infants, who after separation from the placenta depend on external $\mathrm{Cr}$. Cr supplementation of pregnant and lactating women, as well as of babies and infants are likely to be of benefit for child development. Last but not least, $\mathrm{Cr}$ harbours a global ecological potential as an additive for animal feed, replacing meat- and fish meal for animal (poultry and swine) and fish aqua farming. This may help to alleviate human starvation and at the same time prevent overfishing of oceans.

Keywords Creatine kinase isoforms . Microcompartments - Beneficial effects of creatine supplementation 


\section{Introduction}

Creatine $(\mathrm{Cr})$ has emerged as a safe nutritional supplement not only to increase muscle mass and performance, prevent disease-induced muscle atrophy and improve rehabilitation, but also to strengthen cellular energetics in general (see Salomons and Wyss 2007). The latter represents the physiological basis for the beneficial effects of $\mathrm{Cr}$ supplementation in the treatment of multiple pathologies that display bioenergetic dysregulation, such as myopathies or neurodegenerative diseases (see Andres et al. 2008). Although $\mathrm{Cr}$ effects are likely due to pleiotropic cellular functions, its main role is in the creatine kinase $(\mathrm{CK} / \mathrm{PCr})$ system for temporal and spatial energy buffering. Interdisciplinary approaches in the frame of a system bioenergetics have been successfully applied in the past and will further be necessary to understand the $\mathrm{CK} / \mathrm{PCr}$ system in more detail (Saks et al. 2006a; Saks 2007). This review first summarizes the fundamental knowledge that has been accumulated on the complex $\mathrm{CK} / \mathrm{PCr}$ system over the last three decades, and in a second part gives an overview on the pleiotropic effects of $\mathrm{Cr}$ related to $\mathrm{Cr}$ supplementation as an adjuvant therapy in various pathologies. Exciting new discoveries related to anti-oxidant and anti-apoptotic effects, as well as protection of membranes by $\mathrm{PCr}$ are also discussed with respect to cell protection by $\mathrm{Cr}$.

\section{The CK/PCr system for temporal and spatial buffering and regulation of cellular energetics}

\section{Creatine and creatine kinase}

Although ATP represents the universal energy currency in all organisms and cells, ATP levels are not simply upregulated in cells with high and/or intermittently fluctuating energy demand. Elevation of the intracellular ATP concentration [ATP], as an immediate energy reserve, followed by its hydrolysis, would lead to a massive accumulation of ADP plus $\mathrm{P}_{\mathrm{i}}$ and also liberate $\mathrm{H}^{+}$, acidifying the cytosol. Since this would inhibit ATPases, such as the myofibrillar acto-myosin ATPase and consequently muscle contraction, and many other cellular processes, nature has evolved a means to deal with the problem of the immediate replenishment of ATP stores. The so-called phosphagens evolved as high-energy compounds that are "metabolically inert" and as such do not interfere with primary metabolism. One of them, PCr, together with its corresponding kinase, CK, first appeared at the dawn of eukaryotic evolution some one billion years ago (Bertin et al. 2007).

CK catalyses the reversible reaction: $\mathrm{PCr}^{2-}+$ $\mathrm{MgADP}^{-}+\mathrm{H}^{+} \triangleleft-\mathrm{CK}-\triangleright \mathrm{MgATP}^{2-}+\mathrm{Cr}$ and can thus either utilize $\mathrm{PCr}$ (with a higher $\Delta \mathrm{G}$ free energy change than ATP) to regenerate ATP or alternatively capture immediately available cellular energy, storing up to 10 times the amount in the ATP pool. The CK system stabilizes cellular [ATP] at approximately $3-6 \mathrm{mM}$, depending on the cell type, at the expense of [PCr], and thus maintains the intracellular ATP/ADP ratio at a very high level and consequently keeps the $\Delta \mathrm{G}$ free energy change of ATP hydrolysis as high as possible. This guarantees an efficient use of ATP for all types of cellular functions; that is, the energy gained per ATP hydrolysed is kept at a physiological maximum. Resynthesis of ATP by the CK reaction, for example upon activation of muscle contraction, also removes ADP and $\mathrm{H}^{+}$as products of ATP hydrolysis, so that the net product of ATPase plus the CK reaction is liberation of $\mathrm{Pi}$ as a metabolic signal. Thus, the $\mathrm{CK}$ acts not only acts as an energy buffer but also as a metabolic regulator (for review, see Wallimann et al. 1992, 2007).

CK isoforms and their molecular structure

CK, which is crucially involved in a plethora of bioenergetic processes, is particularly important and is expressed at high levels in cells with high energy requirements such as skeletal, cardiac and smooth muscle, kidney, brain and neuronal cells, retina photoreceptor cells, spermatozoa and sensory hair cells of the inner ear (Wallimann et al. 1992, 2007). The most important feature for the cellular functions of the CK/PCr system is the presence of tissue- and cellspecific CK isoforms with defined subcellular locations. All CK isoforms are encoded by separate nuclear genes and, in most tissues, a single cytosolic CK isoform is coexpressed together with a single mitochondrial CK isoform (mtCK). Cytosolic muscle-type CK (M-CK) and brain-type CK (B-CK) form homo-dimers or hetero-dimers, e.g. MM$\mathrm{CK}$ in skeletal muscle, MM-, MB- and BB-CK in heart, or BB-CK in brain, kidney, spermatozoa, skin and many other tissues. MtCK is situated in the outer mitochondrial compartment and occurs as sarcomeric mtCK (smtCK) expressed mainly in muscle tissue and as ubiquitous $\mathrm{mtCK}$ (umtCK) expressed in a large number of other cells and tissues. Both form homo-dimers and homo-octamers, with the latter being the predominant oligomeric form in vivo.

Importantly, CK isoforms are localized differentially on a subcellular level and these specific locations are essential for the functioning of the CK network (Wallimann et al. 1992, 2007). As for many other cellular processes, "location, location is the name of the game" (Hurtley 2009). The proposed CK/PCr energy shuttle (Wallimann 1975; Saks et al. 1978; Bessman and Geiger 1981; Bessman 1986, 1987; Wallimann et al. 1992; Schlattner et al. 2006a, b; Wallimann et al. 2007) connects sites of ATP production (glycolysis and mitochondrial oxidative phosphorylation) with subcellular sites of ATP utilization (ATPases). The 
molecular bases for this spatial energy buffering are functionally coupled, subcellular CK micro-compartments, at sites where ATP production and ATP consumption are tightly connected to $\mathrm{CK} / \mathrm{PCr}$ action. At these subcellular sites, CK reactions may run in different (forward or backward) directions, but on the global cellular or organ level the CK system appears to be as if in equilibrium (see Fig. 1).

The molecular structures of $\mathrm{CK}$ isoforms have been solved at atomic level (Fritz-Wolf et al. 1996; Rao et al. 1998; Eder et al. 1999, 2000a; reviewed by McLeish and Kenyon 2005) and their biochemical characteristics, e.g. enzyme catalysis, oligomerization, membrane interaction and binding to subcellular structures (e.g. Rossi et al. 1990; Eder et al. 2000b; Hornemann et al. 2000; Schlattner et al. 2000; Schlattner and Wallimann 2000; Schlattner et al. 2004) and specific interaction with subcellular partners and domains involved in such interactions (Kraft et al. 2000; Hornemann et al. 2003) have been studied in detail over the past decades. These studies have revealed important aspects of structure-function relationships and molecular physiology of CK that has allowed an understanding of the $\mathrm{CK} / \mathrm{PCr}$ system and its eminent physiological role (Schlattner et al. 2006a; Wallimann et al. 2007).
Temporal and spatial energy buffering

Cr derived either from endogenous synthesis in the body or taken up from alimentary sources, e.g. meat and fish, is transported into muscle and other target cells with high and fluctuating energy requirements by a specific creatine transporter (CRT) (Speer et al. 2004; Straumann et al. 2006; see Fig. 1 with respective labels and numbering used in the following text). Imported $\mathrm{Cr}$ is charged to the highenergy compound $\mathrm{PCr}$ by the action of either strictly soluble, cytosolic CK (CK-c, (3)), by CK coupled to glycolysis (CK-g, (2)) or by mtCK coupled to oxidative phosphorylation (OP) $(\mathbf{m t C K},(\mathbf{1}))$. In a resting cell, this results, at equilibrium, in a distribution of the total $\mathrm{Cr}$ pool into approximately two-thirds [PCr] and one-third [Cr] and in a very high ATP/ADP ratio $(\geq 100: 1)$. A fraction of cytosolic isoforms of $\mathrm{CK}$ are specifically associated with ATP-consuming processes (CK-a, (4)), such as the myofibrillar acto-myosin ATPase, the SR $\mathrm{Ca}^{2+}$-ATPase, the plasma membrane $\mathrm{Na}^{+} / \mathrm{K}^{+}$-ATPase, the ATP-gated $\mathrm{K}^{+}$channel or ATP-requiring constituents for cell signalling.

Within these functional micro-compartments, CK regenerates the utilized ATP, drawing from the large $\mathrm{PCr}$ pool. These micro compartments with associated $\mathrm{CK}$

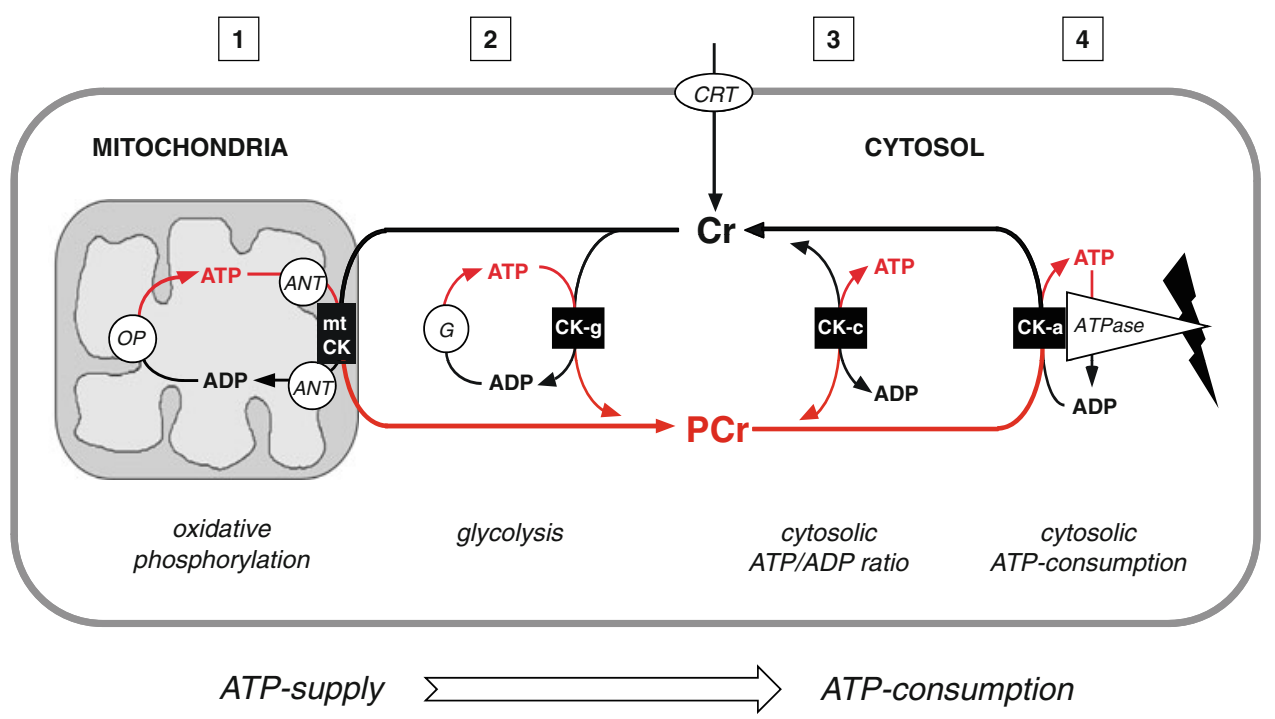

Fig. 1 The CK/PCr system for temporal and spatial energy buffering in cells of high and fluctuating energy requirements. $\mathrm{Cr}$ enters the target cells via $\mathrm{Cr}$ transporter (CRT). Inside the cell, $\mathrm{PCr} / \mathrm{Cr}$ and ATP/ ADP equilibria are adjusted by a soluble fraction of cytosolic CK isoforms (CK-c, see (3)). Another fraction of cytosolic CK (CK-g, see (2)) is specifically coupled to glycolytic enzymes (G), accepting glycolytic ATP, while mitochondrial CK isoforms (mtCK, see (1)) is coupled to adenine nucleotide translocator (ANT), thus accepting ATP exported from the matrix and generated by oxidative phosphorylation (OP). The contribution of both of these so-called microcompartments to total $\mathrm{PCr}$ generation depends on the cell type. The $\mathrm{PCr}$ thus generated is fed into the large PCr pool (up to $30 \mathrm{mM}$ ) that is available as a temporal or spatial energy buffer. Another fraction of cytosolic CK (CK-a, see (4)) specifically associated with subcellular sites of ATP utilization (ATPase, e.g. ATP-dependent or ATP-gated processes, ion-pumps etc.) also forms tightly coupled microcompartments regenerating the ATP utilized by the ATPase reaction in situ on the expense of PCr. The proposed CK/PCr energy shuttle or circuit connects, via highly diffusible $\mathrm{PCr}$ and $\mathrm{Cr}$, subcellular sites of ATP production (glycolysis and mitochondrial oxidative phosphorylation) with subcellular sites of ATP utilization (ATPases). This model is based on functionally coupled, subcellular CK microcompartments, where ATP production and ATP consumption are tightly connected to CK/PCr action (Wallimann 1975; Wallimann and Eppenberger 1985; Schlattner et al. 2006a; Wallimann et al. 2007) 
represent the $\mathrm{ATP} / \mathrm{PCr}$-consuming side of the $\mathrm{CK} / \mathrm{PCr}$ system (4). At the ATP/PCr-generating side of the system, there are the glycogenolytic/glycolytic CK-g microcompartments (2) and the mtCK microcompartment connected to OP and energy channelling reactions inside the mitochondrion (1) (Schlattner et al. 2006b). MtCK is specifically located in the intermembrane space of mitochondria with preferential access to ATP generated by OP via adenine nucleotide translocator (ANT) of the mitochondrial inner membrane. This mitochondrial ATP is trans-phosphorylated into $\mathrm{PCr}$ that then leaves the mitochondria (Dolder et al. 2003). This route of ATP generation is most important for refilling the $\mathrm{PCr}$ energy store in oxidative tissues, e.g. upon extensive stimulation of muscle contraction and thus is relevant for recovery after exhausting exercise (Quistorff et al. 1993).

A large cytosolic PCr pool of up to $30 \mathrm{mM}$ is built up by CK using ATP predominantly from OP (1) as in the heart, or from glycolysis (2) plus OP (1) as in skeletal muscle. $\mathrm{PCr}$ is then used to buffer global cytosolic (3) and local (4) ATP/ ADP ratios. This would represent the temporal buffer function of the system. This function has been confirmed using reverse genetic approaches. For example, by introducing a phosphagen kinase gene, the $\mathrm{CK}$ orthologue arginine kinase (AK), into Escherichia coli or yeast, a phospho-arginine pool was built up that improved recovery of the bacteria and yeast from transient $\mathrm{pH}$ stress (Canonaco et al. 2002, 2003). By a similar strategy, yeast cells into which the genes for the enzymes for $\mathrm{Cr}$ biosynthesis (AGAT and GAMT) plus CK were introduced, proved to be resistant to metabolic stressors, such as low $\mathrm{pH}$ and starvation, by stabilizing the ATP levels during the transient stress period to pre-stress levels (Canonaco et al. 2002).

In cells that are polarized and/or have very high or localized ATP consumption (4), the differentially localized $\mathrm{CK}$ isoforms, together with easily diffusible $\mathrm{PCr}$ and $\mathrm{Cr}$, maintain a high-energy $\mathrm{PCr} / \mathrm{Cr}$-circuit between ATP-providing $(\mathbf{1}, \mathbf{2})$ and ATP-consuming processes $(\mathbf{3}, \mathbf{4})$. Thus, the energy producing and consuming terminals of the shuttle are connected via $\mathrm{PCr}$ and $\mathrm{Cr}$, with no obligatory need for ATP or ADP to diffuse, for example, from mitochondria (1) to the sites of ATPases (4) or backwards, respectively. Metabolite channelling (Schlattner et al. 2011) occurs where CK is associated with ATP-providing $(\mathbf{1}, \mathbf{2})$ or ATP-consuming processes $(4)$, that may be represented by ATPases, such as the actin-activated myosin MgATPase for muscle contraction (Wallimann et al. 1984; Ventura-Clapier et al. 1987; van Deursen et al. 1993) and actin-based cell motility (Kuiper et al. 2009), ATPdependent ion-pumps and transporters, such as the SR $\mathrm{Ca}^{2+}$ pump (Rossi et al. 1990; de Groof et al. 2002), the $\mathrm{Na}^{+} / \mathrm{K}^{+}$-ATPase (Guerrero et al. 1997), the gastric $\mathrm{H}^{+} / \mathrm{K}^{+}$ATPase (Sistermans et al. 1995b), as well ATP-gated ion- channels (Dzeja and Terzic 1998), ATP-requiring metabolic enzymes and protein kinases, such as AMP-activated protein kinase (AMPK) (Ceddia and Sweeney 2004) or Akt/PKB (Deldicque et al. 2007, 2008) involved in cell signalling (Saks et al. 2006b; Wallimann et al. 2007).

\section{$\mathrm{CK}$ in specialized polarized and epithelial cells}

$\mathrm{CK}$ is not only prominent in sarcomeric skeletal and cardiac muscle, where MM-CK is co-expressed with smtCK and where these isoforms are located at specific subcellular sites (Wegmann et al. 1992), but also in smooth muscle, brain and other non-muscle tissues where BB-CK is coexpressed with umtCK (Wallimann et al. 1992). For example, BB-CK is highly expressed in spermatozoa, retina photoreceptor cells (Wallimann and Hemmer 1994) as well as in the sensory hair cells present in the inner ear (Shin et al. 2007). The common denominator of these cells is that they are highly polar, elongated cells and that mitochondria are located at a distance from intracellular sites of ATP consumption. Therefore, these cells are the best models to investigate how mitochondrial-generated high-energy phosphates reach the sites of ATP consumption when separated by a long diffusion distance.

\section{CK in spermatozoa}

In sea urchin sperm, $100 \%$ of the energy required for sperm tail movement is generated in one single large mitochondrion located in the mid-piece behind the sperm head (Fig. 2). Mitochondria from sea urchins and other organisms harbour high concentrations of octameric mtCK (Wallimann et al. 1986a; Tombes and Shapiro 1987; Kaldis et al. 1996b), whereas the sperm tails contain a "cytosolic" $\mathrm{CK}$ which in sea urchins is a contiguous CK trimer (Quest et al. 1997), but in other organisms consists of brain-type BB-CK dimers (Wallimann et al. 1986a; Kaldis et al. 1996b). Most of the sperm tail CK is distributed along the entire sperm tail and/or associated with the cell membrane and the dynein ATPase (Quest et al. 1997).

In vivo experiments examining flagellar wave bending of living sea urchin sperm, which after activation were incubated with dinitrofluorobenzene (DNFB), a specific inhibitor of $\mathrm{CK}$, showed that increasing concentrations of DNFB attenuated firstly flagellar wave bending, and the amplitude of bending, at the very distal end of the sperm tail. As DNFB concentrations were increased, flagellar wave attenuation was gradually and progressively affected towards the more proximal regions and the mid-piece (Tombes et al. 1987). Similar results had been obtained with chicken sperm (Wallimann et al. 1986a). This was a first and very elegant visual demonstration showing that with progressive inhibition of $\mathrm{CK}$, the diffusion distances for 


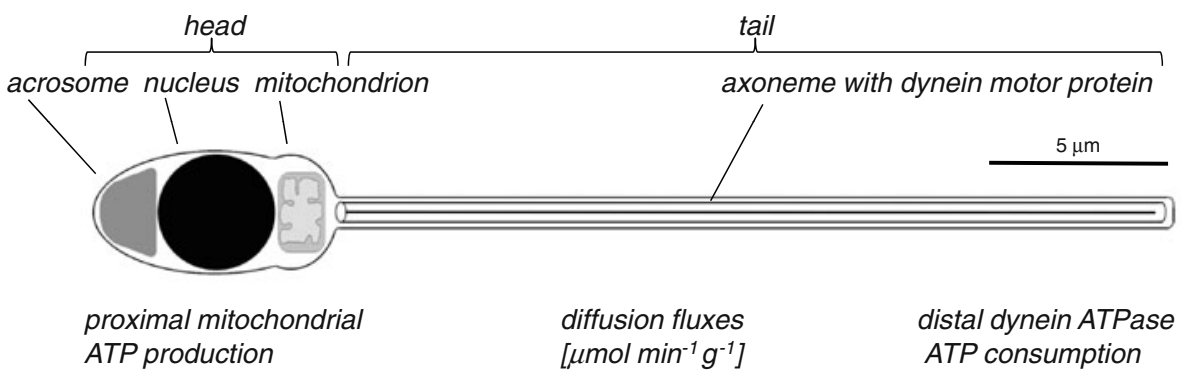

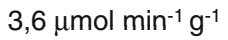

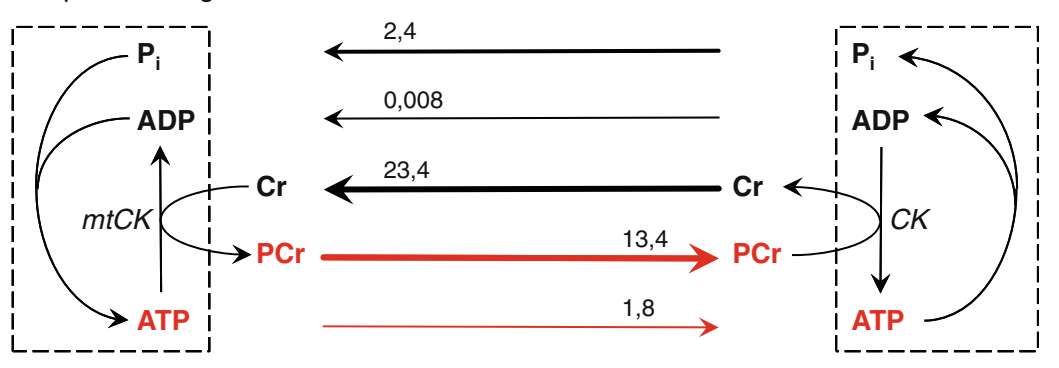

Fig. 2 Spatial energy buffering by the $\mathrm{CK} / \mathrm{PCr}$ : the $\mathrm{PCr} / \mathrm{Cr}$-shuttle in spermatozoa. Diffusion fluxes in sea urchin sperm were calculated from in vivo ${ }^{31} \mathrm{P}-\mathrm{NMR}$ saturation transfer NMR experiments (Kaldis et al. 1997). The diffusion flux of ADP from the sperm tail end towards the mitochondrion located at the mid piece is more than 2,000 times slower compared with that of $\mathrm{Cr}$, whereas the diffusion flux of ATP from the region of the mitochondrion towards the sperm tail is roughly seven times slower than that of PCr. Thus, the $\mathrm{PCr} /$ $\mathrm{Cr}$-shuttle is a physiological adaptation to overcome the diffusional

ATP from the mitochondrion to the very end of the sperm tail are indeed limited and that after inhibition of tail CK they are no longer compensated for by $\mathrm{PCr} / \mathrm{Cr}$ diffusion.

Using in vivo ${ }^{31} \mathrm{P}-\mathrm{NMR}$ saturation transfer, high-energy phosphate concentrations as well as the rate of flux through the CK reaction were measured before and after activation of intact live sea urchin sperm in sea water (van Dorsten et al. 1996, 1997), combined with concomitant measurement of $\mathrm{O}_{2}$ consumption (ATP production). Knowledge of the metabolite concentrations together with their diffusion constants then allowed the calculation of diffusion fluxes of the respective metabolites (Kaldis et al. 1997). As shown in Fig. 2, PCr and $\mathrm{Cr}$ display a significantly higher diffusion flux compared with ATP and ADP. Most remarkably, the diffusion flux of ADP from the distal sperm tail end back to the mid-piece mitochondrion is slower by three orders of magnitude compared with $\mathrm{Cr}$ (Kaldis et al. 1997). Thus, the $\mathrm{CK} / \mathrm{PCr}$ shuttle is compensating for the diffusion limitations of mainly ADP and somewhat less so of ATP.

\section{CK in retina photoreceptor cells}

Similar findings on the importance of the CK/PCr system working as a spatial buffer have recently been presented for elongated photoreceptor cells of the retina (Linton et al. limitations of adenosine nucleotides, especially of ADP, to facilitate long-distance energy transport, as well as high-throughput fluxes of cellular energy. A similar system has been proposed and proved to work also in the sensory hair cells of the inner ear (Shin et al. 2007) and in the polar photoreceptor cells of the retina (Wallimann et al. 1986b; Hemmer et al. 1993; Linton et al. 2010) and in the sensory hair cells of the inner ear (Shin et al. 2007). (Figure adapted from Kaldis et al. 1997)

2010). CK isoforms are expressed in all cells of the retina, but the highest levels of CK are found in the polar photoreceptor cells (Wallimann et al. 1986b), where cytosolic $\mathrm{BB}-\mathrm{CK}$ and umtCK are located in the inner segments and some BB-CK in the outer segments of the photoreceptor cells of certain species, e.g. in bovine rod outer segments (Wegmann et al. 1991; Hemmer et al. 1993). It was postulated that this compartmented intracellular distribution of CK isoforms could induce an energy flux carried by the $\mathrm{CK} / \mathrm{PCr}$ system. It would emanate from the mitochondria clustered centrally within the photoreceptor cells and propagate in two directions, towards the synapse as well as into the outer segment towards the photoactive membrane stacks in the rod outer segments (Wallimann et al. 1986b).

Most recently, it has been shown by biochemical and electrophysiological measurements that the $\mathrm{CK} / \mathrm{PCr}$ system is indeed fundamental to energy distribution in photoreceptors. In darkness, $\mathrm{PCr}$ emanating from the central mitochondria of the photoreceptor cells flows into the synaptic terminal, where the ATP required for sustained glutamate release (dark current) is regenerated by cytosolic CK that is localized at this shuttle terminal (Linton et al. 2010). Since we found BB-CK, albeit at lower levels, also in the bovine rod outer segments (Hemmer et al. 1993), it is conceivable that such a vectorial $\mathrm{PCr}$ energy transport not 
only runs in one direction towards the synaptic terminal, but also in the opposite direction into the rod outer segments. There, bound CK would convert PCr into ATP used for photoreceptor signalling, that is, for stabilizing the [ATP] needed for resynthesis of cGMP from GTP upon photic stimulation (Hemmer et al. 1993).

$\mathrm{Cr}$ supply to the retina is important and seems to be supported by a dual system: (a) by uptake from the circulation via CRT expressed in the endothelial cells of the blood/retinal barrier, and (b) by endogenous $\mathrm{Cr}$ synthesis in the Müller glia cells (Tachikawa et al. 2007). Chorioretinal degeneration in patients with gyrate atrophy, who present with a Cr-deficiency syndrome, can be ascribed both to a reduced $\mathrm{Cr}$ supply from circulating blood and a disrupted endogenous $\mathrm{Cr}$ supply to the retina from the local Müller glia due to inhibition of $\mathrm{Cr}$ biosynthesis by hyper-ornithinemia (Sipila 1980). This indicates that the $\mathrm{CK} / \mathrm{PCr}$ system is physiologically important for vision, even though up to date no phenotype for visual defects has been reported in transgenic CK knockout mice (see below).

\section{CK in hair cells of the inner ear}

Brain-type cytosolic BB-CK has been also localized in the inner ear hair cells (Spicer and Schulte 1992). CK was identified, by a proteomic approach with isolated hair cells from purified vestibular bundles, as the second most prominent protein besides actin, and other proteins of the cytoskeleton and proteins involved in $\mathrm{Ca}^{2+}$ homeostasis, stress response and glycolysis (Shin et al. 2007). Present at a high concentration of approximately $0.5 \mathrm{mM}$ inside the sensory hair cells, the CK enzyme is capable of maintaining constant ATP levels despite a turnover of $1 \mathrm{mM}$ ATP/s. This turnover is imposed by the plasma membrane $\mathrm{Ca}^{2+}$-ATPase pump that maintains $\mathrm{Ca}^{2+}$-cycling during activation of these specialized sensory cells. The polarized hair bundle cells cannot rely on ATP diffusion and it was shown that the $\mathrm{CK} / \mathrm{PCr}$ shuttle is essential for high-sensitivity hearing and vestibular function, e.g. body balance and equilibrium. CK knockout mice presented with hearing loss and a strong vestibular phenotype (Shin et al. 2007). Interesting in this context is the fact that $\mathrm{Cr}$ supplementation of healthy wild-type mice significantly attenuates noise-induced destruction of inner and more so of outer hair cells and the concomitant hearing loss (Minami et al. 2007). These data indicate that the maintenance of ATP levels by the CK/PCr system, possibly together with antioxidant properties of $\mathrm{Cr}$, are important for attenuating temporary and permanent noise-induced hearing loss. Thus, Cr supplementation may be recommended as a preventive measure in professionally noise-exposed individuals.
CK in epithelial cells

Rather surprisingly, high concentrations of CK isoforms were also found in a variety of epithelial cells that are not known to have high fluctuating energy requirements, but may need energetic support for maintaining high rates of cell divisions, resorption or secretion activities. In stomach epithelium parietal cells, the $\mathrm{CK} / \mathrm{PCr}$ system appears to work in conjunction with the $\mathrm{H}^{+} / \mathrm{K}^{+}$-ATPase pump and is involved in gastric acid secretion (Sistermans et al. 1995b). In epithelial cells of the intestine (Sistermans et al. 1995a) CK may be involved in food absorption and transport, as well as cell renewal. In skin, BB-CK and umtCK have been localized in the keratinocytes of the highly proliferative suprabasal layer of the epidermis, as well as in the hair follicles and sebaceous glands (Schlattner et al. 2002), indicating a function of the CK/PCr system for normal skin function (Zemtsov 2007), proliferation and hair growth (Schlattner et al. 2002). During wound healing, CK isoforms were highly upregulated indicating a function of CK and $\mathrm{Cr}$ (Schlattner et al. 2002). In accordance with the postulated important functions of the CK system in skin, topical application of a $\mathrm{Cr}$ containing lotion directly onto skin has been shown to exert a marked protection from UV-induced oxidative damage and mutagenesis in vitro (Berneburg et al. 2005) and in vivo (Lenz et al. 2005).

There is still a widely expressed concern that $\mathrm{Cr}$ supplementation may be deleterious to the kidney. This, unfortunately, has to do with the fact that creatine $(\mathrm{Cr})$ is still mixed-up with creatinine ( $\mathrm{Crn})$. $\mathrm{Crn}$ is the cyclic degradation product of $\mathrm{Cr}$ that is generated by non-enzymatic conversion from $\mathrm{Cr}$, until a roughly $2 / 3-1 / 3$ chemical equilibrium between $\mathrm{Crn}$ and $\mathrm{Cr}$ is established. Crn content is measured as a kidney function marker in the serum of patients because it is very prominent and easy to measure chemically. While an accumulation of $\mathrm{Crn}$ in the serum normally indicates that kidney function is impaired, this is entirely unrelated to the somewhat higher serum $\mathrm{Cr}$ and/or Crn concentrations during $\mathrm{Cr}$ supplementation which, in this case, is not indicative of kidney malfunction or any general toxicity. As the Crn concentration may increase somewhat with $\mathrm{Cr}$ supplementation (Schedel et al. 1999), due to the chemical equilibrium reaction between $\mathrm{Cr}$ and $\mathrm{Crn}$, this is often taken as a false argument for impairment of kidney function, but in fact is a normal consequence of $\mathrm{Cr}$ intake. On the contrary, $\mathrm{CK}$ and $\mathrm{Cr}$ are important for kidney function. CK is highly expressed in kidney epithelial cells (Wallimann and Hemmer 1994) and the CK/PCr system supports $\mathrm{Na}^{+} / \mathrm{K}^{+}$-ATPase ion pump function in the kidney (Guerrero et al. 1997). In addition, kidney proximal tubule epithelial cells also express $\mathrm{Cr}$ transporter (CRT) that is responsible for resorption and salvaging of $\mathrm{Cr}$, a valuable guanidino compound, from the urine $(\mathrm{Li}$ et al. 
2010). So, one may argue that if $\mathrm{Cr}$ would be deleterious for the kidney, why would the kidney absorb $\mathrm{Cr}$ from the urine instead of secreting it? Indeed, in a placebo-controlled double-blind clinical study, involving healthy men, $\mathrm{Cr}$ supplementation at $10 \mathrm{~g} /$ day for 3 months had no deleterious effect on kidney function (Gualano et al. 2008b). In a single case study concerning a man with only one kidney, who presented with a mildly decreased glomerular filtration rate, no $\mathrm{Cr}$-induced deleterious effects of $\mathrm{Cr}$ supplementation (20 g/day for 30 days) were observed (Gualano et al. 2010). Even long-term Cr supplementation ( $4 \mathrm{~g} /$ day for 2 years) is today considered safe, as seen in aged Parkinson patients (Bender et al. 2008b). Thus, $\mathrm{Cr}$ taken at the recommended dosage in a chemically pure form is not deleterious to kidney function and health.

Functions of cytosolic CK associated with glycolysis

A fraction of cytosolic CK is associated with the glycolytic enzyme complex (Fig. 1, (2)) that, in sarcomeric muscle, is concentrated at the myofibrillar I-band (Kraft et al. 2000). It was shown that there, $\mathrm{CK}$ is specifically associated with those glycolytic enzymes that are either involved in ATP generation, such as pyruvate kinase (PK) (Dillon and Clark 1990; Kraft et al. 2000) or with the main regulatory enzyme of glycolysis, phosphofructokinase (PFK), which is regulated by rising [ATP] via a negative feed-back mechanism of ATP on PFK (Kraft et al. 2000). The CK-PFK interaction is $\mathrm{pH}$-dependent and stronger at lower $\mathrm{pH}$ than at neutrality. This is physiologically relevant since under conditions of muscle activation and working glycolysis, the intracellular $\mathrm{pH}$ may drop. Thus, if glycolysis is initiated immediately after contraction to produce ATP, the close structural and functional association of $\mathrm{CK}$ with distinct members of the glycolytic micro-compartment makes sense in two ways: (a) glycolytic ATP is immediately removed from this compartment by associated $\mathrm{CK}$ and thus inhibition of glycolysis by negative feed-back regulation via ATP accumulation is prevented, and (b) glycolytic ATP can be used concomitantly to reduce the depletion of the $\mathrm{PCr}$ pool during contraction (Kraft et al. 2000; Wallimann et al. 2007). The principle of tight functional coupling of glycolysis to $\mathrm{CK}$ action has been shown in vitro in a system of reconstituted glycolysis containing CK (Scopes 1973) and also in vivo in an anoxic goldfish model (van den Thillart et al. 1989) where mitochondrial function is basically eliminated due to lack of oxygen. There, clearly, glycolytic ATP was shown to be used to replenish the $\mathrm{PCr}$ pool, although not to the maximal extent (van den Thillart et al. 1989; Van Waarde et al. 1990).

The coupling of CK to the glycogenolytic/glycolytic pathway is also supported by gated ${ }^{31} \mathrm{P}-\mathrm{NMR}$ measurements following at very high time-resolution the metabolite fluctuations elicited by single muscle contractions (Chung et al. 1998). After a single contraction the recovery of $\mathrm{PCr}$ is much faster than at the end of stimulation. This implies a distinct recovery mechanism in the first phase, which is in line with the contention that a significant proportion of glycogenolytic/glycolytic ATP is immediately used and trans-phosphorylated by $\mathrm{CK}$ to replenish $\mathrm{PCr}$ (see also Shulman 2005). After the end of stimulation, however, $\mathrm{PCr}$ recovery kinetics is consistent with a predominant role of OP (van den Thillart et al. 1989; Van Waarde et al. 1990; Quistorff et al. 1993; Chung et al. 1998). Finally, transgenic CK knock-out mice show an altered glycolytic network in their CK-deficient muscles (de Groof et al. 2001a), which also indicates an intricate interconnection of the two systems. This is corroborated by the fact that muscles of PFK-deficient patients show a dramatic delay in $\mathrm{PCr}$ recovery following exercise (Grehl et al. 1998).

Functions of mitochondrial CK (mtCK)

\section{Metabolite channelling in the mtCK microcompartment}

After the import of nuclear encoded, nascent mtCK through the mitochondrial outer membrane and cleavage of the $\mathrm{N}$-terminal targeting sequence, mtCK first assembles into dimers. These dimers rapidly associate into octamers and although this reaction is reversible, octamer formation is strongly favoured by the high mtCK concentration in the inter-membrane space (Schlattner et al. 2006a). The symmetrical and cube-like mtCK octamers (Fritz-Wolf et al. 1996; Eder et al. 2000a) then directly bind to acidic phospholipids in the mitochondrial membranes (Fig. 3), preferentially to cardiolipin of the inner mitochondrial membrane (Schlattner et al. 2004), and in a calciumdependent manner directly to VDAC (Schlattner et al. 2001). Affinity of both ANT and mtCK for cardiolipin situates them in common cardiolipin patches (Fig. 3), which can also be induced by membrane-bound mtCK (Epand et al. 2007b), thus allowing for a functional interaction between both proteins (Wallimann et al. 1998; Schlattner et al. 2006b). MtCK is found in two locations (Wegmann et al. 1991): (a) in the so-called mitochondrial contact sites (Fig. 3), where mtCK simultaneously binds to inner and outer membrane due to its symmetrical octameric structure (see below) and where it functionally associates with ANT and VDAC (Kottke et al. 1991) and (b) in the cristae (not shown) associated with inner membrane and ANT only (Wegmann et al. 1991; for details, see Schlattner et al. 2006a, 2011). A well-coupled MtCK micro compartment is also maintained by diffusion restrictions for adenylates at the outer membrane VDAC, possibly via direct interaction of VDAC with tubulin (Rostovtseva et al. 2008). The preferred or exclusive substrate and product fluxes in a 


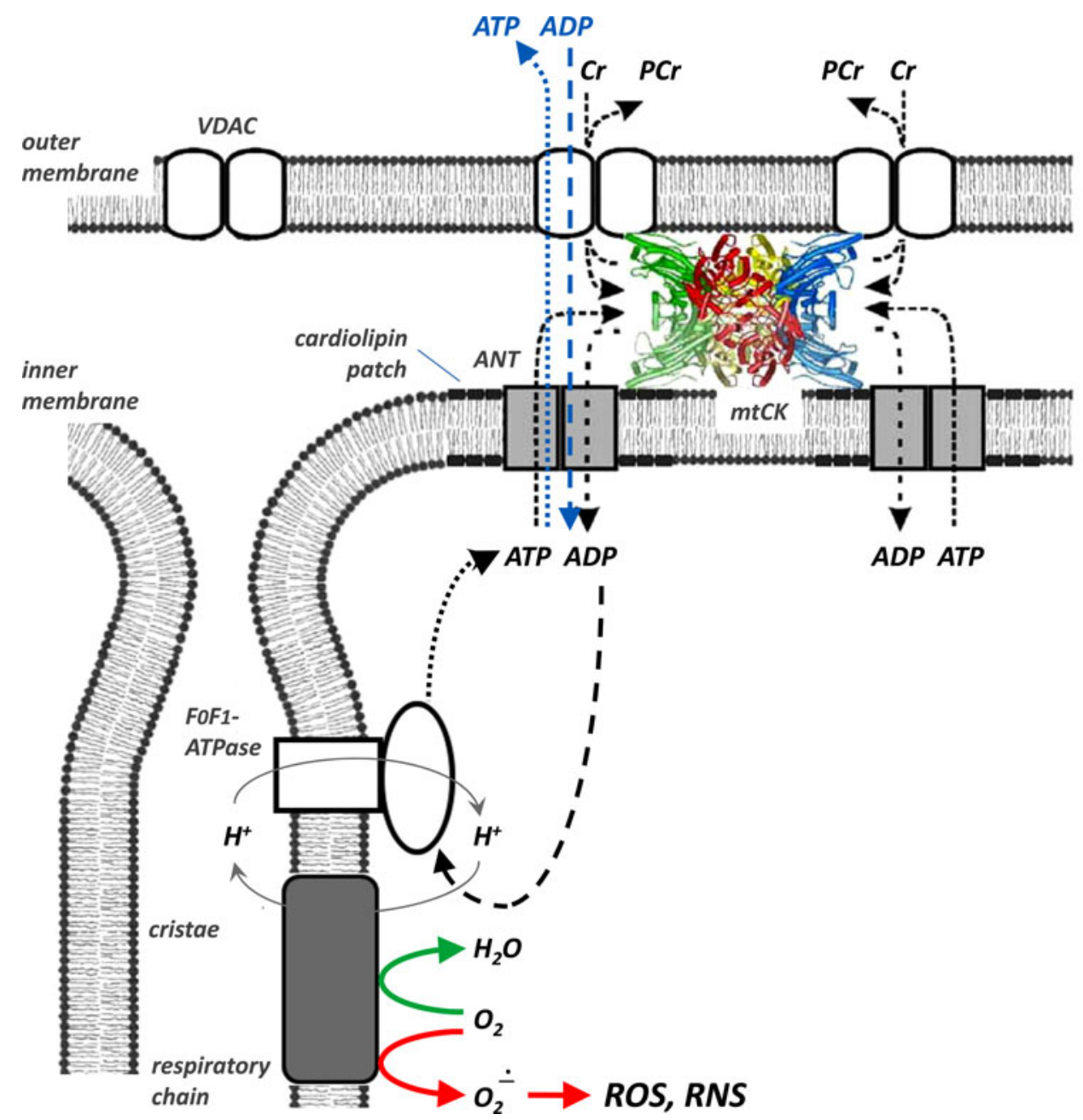

Fig. 3 Mitochondrial mtCK functions for high-energy metabolite channelling in mitochondria. In cells with oxidative metabolism, respiration (green arrow), ATP synthesis and ATP export through the inner mitochondrial membrane via adenine nucleotide transporter (ANT) are tightly coupled to trans-phosphorylation of ATP to PCr by $\mathrm{mtCK}$ and export of $\mathrm{PCr}$ into the cytosol by the outer membrane voltage-dependent anion channel (VDAC) as indicated by black arrows. In turn, $\mathrm{Cr}$ stimulates respiration by favoring constant supply of ADP to the matrix (black arrows), which also lowers ROS/RNS production in the intra-mitochondrial space (red arrows) and inhibits mitochondrial permeability transition. The tight coupling of substrate and product fluxes (black arrows) allows a so-called channeling of "high-energy" metabolites, with $\mathrm{PCr}$ being the one released into the cytosol, and ATP/ADP being mainly recycled within the

well-coupled mtCK microcompartment are indicated in Fig. 3 by black arrows (Saks et al. 2000); minor or alternative fluxes at a lower degree of coupling are shown with blue arrows.

According to this scheme, ATP generated by OP via the $\mathrm{F}_{0} \mathrm{~F}_{1}$-ATPase is transported through the inner membrane by ANT in exchange for ADP. This ATP may either leave the mitochondrion directly via outer membrane VDAC or is preferentially accepted and trans-phosphorylated into $\mathrm{PCr}$ by octameric $\mathrm{mtCK}$ in the intermembrane space. $\mathrm{PCr}$ then mitochondria. The structural basis of these mtCK microcompartments are proteolipid complexes containing either VDAC, octameric mtCK and ANT in the peripheral intermembrane space (as shown) or octameric mtCK and ANT in the cristae (not shown). These proteolipid complexes are maintained by $\mathrm{mtCK}$ interactions with anionic phospholipids and VDAC in the outer membrane, and with cardiolipin and thus indirectly with cardiolipin-associated ANT in the inner membrane (see cardiolipoin patches). In cases of a less coupled mtCK microcompartment, e.g. after impairment of mtCK function by oxidative damage, there is partial direct ATP/ADP exchange with the cytosol (blue arrows). (Figure adapted from Kaldis et al. 1997; Meyer et al. 2006; Schlattner et al. 2006a; Schlattner et al. 2011) (The different fluxes are indicated by coloured arrows in the figure)

preferentially leaves the mitochondrion via VDAC and feeds into the large cytosolic PCr pool. ADP generated from the mtCK trans-phosphorylation reaction is accepted by ANT and immediately transported back into the matrix to be recharged. In contact sites, this substrate channelling allows for a constant supply of substrates and removal of products at the active sites of mtCK. In cristae, only ATP/ ADP exchange is facilitated through direct channelling to the mtCK active site, while $\mathrm{Cr}$ and $\mathrm{PCr}$ have to diffuse along the cristae space to reach VDAC (not shown; for 
details, see Schlattner et al. 2006a, b; Wallimann et al. 2007).

Functional coupling of ANT to mtCK leads to a saturation of mtCK with ANT-delivered ATP, and at the same time to a locally high ATP/ADP ratio in the vicinity of mtCK. In combination with cytosolic $\mathrm{Cr}$, entering the intermembrane space via VDAC, these conditions are favourable to drive the synthesis of PCr from ATP by mtCK without loss of energy content. This maintains maximal thermodynamic efficiency for high-energy phosphate synthesis and channelling, which in the form of $\mathrm{PCr}$ is exported into the cytosol (Dolder et al. 2003). Such a reaction sequence represents an instructive example of functional coupling and metabolite channelling. The active ATP/ADP exchange maintained by coupled mtCK favours ATP generation by the $\mathrm{F}_{0} \mathrm{~F}_{1}$-ATPases and thus proper functioning of the respiratory chain, which could otherwise generate elevated levels of superoxide and reactive oxygen species (ROS) (Schlattner et al. 2011).

The intricate functional coupling of mtCK to the ANT (Vendelin et al. 2004), leading to a saturation of the ANT on the outer site of the inner membrane with ADP, which then is transported back into the matrix to be recharged by the $\mathrm{F}_{0} \mathrm{~F}_{1}$-ATPase, efficiently couples substrate oxidation to ATP generation. Such tight coupling, by avoiding futile electron transfer, conceivably also would lower the production of free oxygen radicals (ROS). Indeed, mitochondrial respiration in the presence of $\mathrm{Cr}$ needs only micromolar concentrations of ADP to be fully stimulated, whereas in the absence of $\mathrm{Cr}$ comparably high concentration of ADP in the millimolar range are needed for a similar respiratory rate (Kay et al. 2000; Saks et al. 2000). This important phenomenon, termed "creatine-stimulated respiration" is entirely dependent on the presence of mtCK, for mitochondrial respiration can no longer be stimulated by $\mathrm{Cr}$ in intact chemically skinned muscle fibres or mitochondria isolated from cardiac or skeletal muscle of smtCK knockout mice (Kay et al. 2000). Finally, Cr exerts a strong indirect anti-oxidant effect by significantly reducing the intra-mitochondrial production of ROS, as well as elevating and preserving the mitochondrial membrane potential (Meyer et al. 2006). These Cr-meditated events may represent the basis for some of the remarkable neuro-protective effects of $\mathrm{Cr}$ that had been discovered recently (reviewed by Andres et al. 2008).

\section{$M t C K$ and mitochondrial membranes}

Both, sarcomeric smtCK (Fritz-Wolf et al. 1996) and ubiquitous umtCK (Eder et al. 2000a) show cube-like octameric structures of mtCK with approximately $100 \AA$ side lengths, built by four identical mtCK dimers that are arranged by fourfold symmetry around a central channel of approximately $20 \AA$ in diameter. These octamers maintain multiple and complex interactions with the phospholipids of the mitochondrial membranes (reviewed by Schlattner et al. 2006b). By their identical top and bottom faces, which each expose four C-termini, MtCK binds strongly to anionic phospholipids, in particular cardiolipin that is abundant in the inner mitochondrial membrane. By virtue of their molecular symmetry, mtCKs are also able to crosslink two membranes. Both membrane-binding and crosslinking characteristics of $\mathrm{mtCK}$ have been thoroughly investigated and quantified by a number of biophysical techniques (Rojo et al. 1991; Stachowiak et al. 1996, 1998; Schlattner et al. 2004). By site-directed mutagenesis, a cluster of positively charged amino acids at the C-termini has been identified as responsible for mtCK's ability to specifically attach to cardiolipin-containing membranes (Schlattner et al. 2004; Schlattner et al. 2006a). Binding of mtCK with mitochondrial membranes takes place in two phases (Schlattner et al. 2004). The first phase of mtCK attachment is mediated by ionic interaction by positively charged amino acid clusters at the $\mathrm{C}$-terminal of $\mathrm{mtCK}$; the second slower phase is mediated by partial insertion of a hydrophobic stretch into the membrane bilayer (Schlattner et al. 2006a; Maniti et al. 2010). The ability of mtCK to bind to and cross-link two membranes explains the contact site formation between mitochondrial inner and outer membranes and the resulting mechanical stabilization of mitochondria as shown with liver mitochondria from transgenic mice expressing mtCK (Speer et al. 2005). Also, the formation of the characteristic crystalline intra-mitochondrial "railway-track" inclusions, built of mtCK octamers (Stadhouders et al. 1994) inside of mitochondria of "ragged red fibres" from patients with mitochondrial cytopathies, can be explained by membrane binding of mtCK octamers either peripherally between inner and outer membrane or in the cristae between inner membranes. Once bound to membranes, $\mathrm{mtCK}$ shows a pronounced tendency to form ordered 2D crystalline arrangements (Schnyder et al. 1994). These resemble the sheet-like crystalline inclusions in such patient's mitochondria (Stadhouders et al. 1994). Interestingly, these pathological intra-mitochondrial mtCK crystals that are formed as a result of a compensatory over-expression reaction to an energy deficit (O'Gorman et al. 1997b), can also be induced after $\mathrm{Cr}$ depletion in adult cardiomyocytes by addition of guanidine propionic acid (GPA) (EppenbergerEberhardt et al. 1991). These mtCK inclusions, both in Crdepleted cardiomyocytes and in mitochondrial myopathy patients, disappear upon $\mathrm{Cr}$ supplementation of the cell culture medium or the patients, respectively (EppenbergerEberhardt et al. 1991; Tarnopolsky et al. 2004). Finally, recent data show that $\mathrm{mtCK}$, once bound to cardiolipincontaining membrane vesicles, is able to specifically 
cluster cardiolipin molecules around its molecular surface (Epand et al. 2007b) and, if cross-linked to a second membrane vesicle, mtCK is able to facilitate lipid exchange between the two membranes (Epand et al. 2007a). This of course seems relevant for the structure and physiology of mitochondrial inner/outer membrane contact sites and the pre-apoptotic process of mitochondrial permeability transition pore (MPTP) function.

\section{Control of mitochondrial permeability transition, stabilization of inner/outer mitochondrial membrane complex and anti-apoptotic effects of creatine}

As mentioned earlier, mtCK occupies strategically important dual locations in the intermembrane and the cristae space (Kottke et al. 1991). In the periphery of the mitochondrion, mtCK is part of a protein complex that is involved in the so-called mitochondrial permeability transition (MPT) pore complex (O'Gorman et al. 1997a; Dolder et al. 2003). Although the molecular composition of the pore remains an open question, it seems to involve the adenine nucleotide transporter ANT-1 isoform and the voltage-dependent anion carrier VDAC (Zhivotovsky et al. 2009) together with mtCK (Kroemer et al. 2007). MPT represents an early event in apoptosis that often leads to swelling of mitochondria and release of apoptosis-inducing factors that can be initiated experimentally by exposure of mitochondria to atractyloside, an inhibitor of ANT, and/or by elevation of extra-mitochondrial $\left[\mathrm{Ca}^{2+}\right]$ (Azzolin et al. 2010). Under these conditions, isolated mitochondria from the liver of normal wild-type mice, which do not express mtCK in the liver, undergo swelling and apoptosis. This process can be inhibited by cyclosporine, a potent antiapoptotic drug. On the other hand, transgenic mice that have been engineered to express $\mathrm{mtCK}$ in their liver are protected from apoptosis and its destructive consequences by simple addition of $\mathrm{Cr}$ or its analogue cyclocreatine that is also phosphorylated by the CK reaction (Fig. 4). The extent of protection by $\mathrm{Cr}$ is comparable to that of cyclosporine (Dolder et al. 2003). Thus, Cr is not only involved in stimulating mitochondrial respiration but also works as an effective mitochondrial protectant and anti-apoptotic compound (Brdiczka et al. 2006). This may explain some of the cell-protective effects observed with Cr. For example, transgenic mice expressing $\mathrm{mtCK}$ in their liver acquire, after $\mathrm{Cr}$ supplementation, a remarkable tolerance against hypoxia (Miller et al. 1993) and liver toxins (Hatano et al. 1996), as well as against tumour necrosis factor-induced apoptosis (Hatano et al. 2004). Since PCr has been shown to bind to and protect biological membranes (Saks et al. 1996; Tokarska-Schlattner et al. 2003, 2005a), it is conceivable that the $\mathrm{PCr}$ generated by $\mathrm{mtCK}$ in the mitochondrial intermembrane space would also bind to mitochondrial

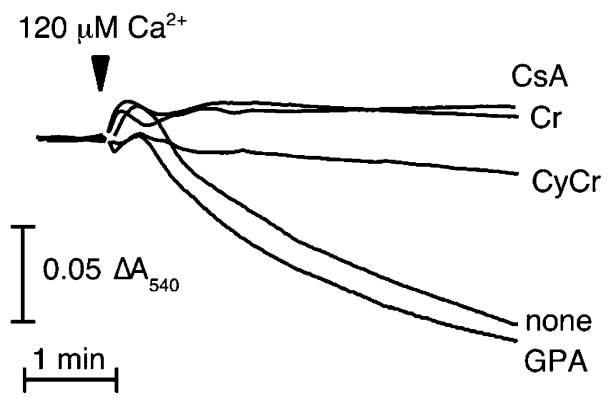

Fig. 4 Mitochondrial permeability transition is inhibited by $\mathrm{CK}$ substrates. At a concentration of $10 \mathrm{mM}$, the CK substrates creatine (Cr) and cyclocreatine (cCr), Cr-analogon, inhibit MTP in isolated mouse liver mitochondria to a comparable degree as $1 \mu \mathrm{M}$ cyclosporin A (CSA), the gold standard for MPT inhibition (Dolder et al. 2003). The Cr-analogon guanidinopropionic acid (GPA) that is not accepted as a substrate by the CK reaction has no effect as compared to control without additions (none). Isolated liver mitochondria from transgenic mice expressing uMtCK in their liver were analysed by a swelling (light scattering) assay. They were energized with glutamate/ malate in presence of $2 \mathrm{mM} \mathrm{Mg}^{2+}$ and then challenged by $120 \mu \mathrm{M}$ $\mathrm{Ca}^{2+}$ where indicated. (Figure taken from Dolder et al. 2003 with permission)

membranes and stabilize them against swelling, as this was shown for plasma membranes of erythrocytes (TokarskaSchlattner et al. 2003, 2005a). Thus, mtCK plus Cr seem to exert cell protection not only by improving cellular energetics, but also by more or less energy-independent actions that also affect apoptosis (O'Gorman et al. 1997a; Brdiczka et al. 2006) (see Table 1).

Phenotypes of CK knockout mice point to important cellular functions of $\mathrm{CK}$ and the $\mathrm{PCr} / \mathrm{Cr}$ system

Ablation of a given gene in transgenic knockout animals is a valuable tool to possibly evaluate the functions of this specific gene, or the respective protein coded by this gene, in an animal. The various constitutive CK knockouts, engineered by the Wieringa Group in Nijmegen NL, illustrates the phenotypical defects caused by the deletion of CK. Ablation of smtCK in muscle is a good example for a positive identification of a $\mathrm{CK}$ function. The fact that $\mathrm{mtCK}$ is required for stimulation of mitochondrial respiration by $\mathrm{Cr}$ (Saks et al. 2000) has been unambiguously corroborated by this technology with mtCK-deficient or double CK knockout mice (Kay et al. 2000).

\section{Adaptation and compensation effects alter knockout phenotypes}

Gene ablation may lead to complex adaptations in the organism to compensate for the loss of function related to the knocked out gene. Some very interesting compensatory events take place in the absence of $\mathrm{CK}$ function. In the 
Table 1 Pleiotropic effects of creatine for cell function and cell protection

\section{Energy-related effects of creatine \\ $\mathrm{Cr}$ improves cellular energy state ( $\mathrm{PCr} / \mathrm{ATP}$ ratio) and muscle performance \\ $\mathrm{Cr}$ facilitates intracellular energy transport ( $\mathrm{PCr}$ circuit or shuttle)}

Cr improves the efficiency of cellular energy utilization

(e.g. for $\mathrm{Ca}^{2+}$-handling)

$\mathrm{Cr}$ stimulates mitochondrial respiration (improved energy provision)

Cr stabilizes mitochondrial PTP complex and thus acts as mitochondrial protectant (anti-apoptotic)

\section{Anti-oxidant and anti-apoptotic effects of creatine}

$\mathrm{Cr}$ acts as a mild direct anti-oxidant (free radical scavenger)

$\mathrm{Cr}$ acts as a strong indirect anti-oxidant in mitochondria

(where ROS production is lowered by tight coupling of respiration/ATP

production to ATP export)

$\mathrm{Cr}$ reduces oxidative damage to DNA, specifically to mtDNA

Cr up-regulates enzymes for oxidative stress defence

$\mathrm{Cr}$ strongly protects in vivo from mitochondrial toxins (Rotenone \& Paraquat)

Cr stabilizes mitochondrial PTP complex and thus acts as mitochondrial protectant (anti-apoptotic)

\section{Other effects of creatine}

$\mathrm{Cr}$ induces differential expression of transcription factors and other genes

$\mathrm{Cr}$ reduces the appearance of inflammation markers

during endurance exercise

$\mathrm{Cr}$ activates cell signalling and enhances muscle cell differentiation

Cr lowers homocysteine levels and lipid peroxidation

(heart risk factors)

$\mathrm{Cr}$ acts as an osmolyte, protecting cells against hypertonic stress

$\mathrm{PCr}$ binds to cell membranes and stabilizes and protects erythrocyte cell membranes
(Harris et al. 1992; Greenhaff et al. 1993)

(Wallimann 1975; Saks et al. 1978, 2006b;

Bessman and Geiger 1981; Wallimann and Eppenberger

1985; Bessman 1986; Wallimann et al. 1992, 1998;

Kaasik et al. 2003; Wallimann et al. 2007)

(Rossi et al. 1990; Steeghs et al. 1997; Pulido et al. 1998; van Leemputte et al. 1999)

(Kay et al. 2000; Meyer et al. 2006)

(O'Gorman et al. 1997a; Dolder et al. 2003;

Hatano et al. 2004)

(Lawler et al. 2002)

(Meyer et al. 2006; Sestili et al. 2006)

(Guidi et al. 2008)

(Young et al. 2010)

(Hosamani et al. 2010)

(O’Gorman et al. 1997a; Dolder et al. 2003; Hatano et al. )

(Hespel et al. 2001; Louis et al. 2004;

Deldicque et al. 2008; Safdar et al. 2008)

(Santos et al. 2004; Bassit et al. 2008)

(Ceddia and Sweeney 2004; Louis et al. 2004;

Deldicque et al. 2007, 2008)

(Deminice et al. 2009)

(Alfieri et al. 2006)

(Saks et al. 1996; Tokarska-Schlattner et al. 2003, 2005a) constitutive CK knockouts, this may lead to a physiological and phenotypical amelioration of the phenotype, thus often hindering the phenotypic expression of a dysfunction related to $\mathrm{CK}$ deletion. As an example for phenotypic compensation, knocking out of $\mathrm{CK}$ in muscle leads to marked changes in mRNA expression profiles involving nuclear and mitochondrial mRNA species that are relevant for bioenergetics (de Groof et al. 2001b), as well as to altered expression of proteins involved in the glycolytic network and mitochondria (de Groof et al. 2001a). Double knock-out of cytosolic and smtCK in muscle also leads to remarkable compensatory adaptation of muscle structure and metabolism, e.g. in white, glycolytic Type II muscle fibres, which normally do not contain large numbers of mitochondria, the CK double knockout animals show a vastly increased mitochondrial propensity and a positioning of these large numbers of mitochondria in such a way that each myofibril is almost completely surrounded by contiguous rows of mitochondria. Thus, these transgenic "glycolytic" muscle fibres look rather like entirely oxidative insect flight muscle (Veksler et al. 1995; VenturaClapier et al. 1995; Steeghs et al. 1998; Ventura-Clapier et al. 2004; Novotova et al. 2006). This points to a compensation in the CK knockouts for reducing diffusion distances for ATP from the mitochondria to the contractile apparatus and thus would support the proposed function of the $\mathrm{PCr}$ shuttle that normally compensates for the diffusion limitations of adenine nucleotides via shuttling of $\mathrm{PCr}$ and Cr. This notion is fully supported by detailed analysis of energy provision in CK knockouts, e.g. by the propinquity of mitochondria to myofibrils enabling ATP/ADP to be channelled directly from mitochondria to myofibrils and back (Kaasik et al. 2003). In addition, the glyocogen content in these muscles is elevated indicating that instead of $\mathrm{PCr}$, glycogen/glucose is taken as a more or less immediate source of energy for muscle contraction. Such 
interesting compensatory alterations give new insight into the kinds of problems that may have been generated in a given tissue by knocking out of either cytosolic and/or mitochondrial $\mathrm{CK}$.

A further interesting observation relates to the fact that CK exists as isoforms and that in a given cell usually a cytosolic CK isoform is co-expressed with a mitochondrial $\mathrm{mtCK}$ isoform, although the relative proportion may vary depending on cell type and organ (Wallimann and Hemmer 1994). After knocking out one CK isoform only the other $\mathrm{CK}$ isoform can at least partially compensate for the function of the other, e.g. cytosolic CK can partially compensate for mtCK (Watchko et al. 2000).

\section{Muscle phenotypes of $C K$ deficiency}

The most obvious CK knockout phenotypes in muscle relate (a) to force development and maintenance, as well as force-velocity relationship, and (b) to muscle relaxation and $\mathrm{Ca}^{2+}$-handling, as well as to (c) CK-mediated membrane metabolic sensing. As to the first, transgenic mice that are completely deficient in muscle CK lack burst activity (van Deursen et al. 1993). The velocity and extent of muscle shortening, power and work after the initial series of stimuli are also significantly lower in the CK knockouts compared to wild type (Watchko et al. 2000). In transgenic mice with graded reduction of $\mathrm{CK}$, muscle burst activity is reduced proportionally to the lowered levels of CK expression (van Deursen et al. 1994). These data are in line with findings that MM-CK is specifically localized at the M-band of sarcomeric muscle, where it regenerates in situ the ATP used for muscle contraction (Saks et al. 1984; Wallimann et al. 1984). In non-muscle cells, ablation of BB-CK leads to altered actin-based phagocytosis (Kuiper et al. 2008) and cell motility of cells cultured from CK knockout animals (Kuiper et al. 2009), indicating that $\mathrm{CK}$ is not only important for muscle contraction but also for phagocytosis and cell motility in general. As to the second, in CK knockout muscle, muscle relaxation time was longer, with changes also in intracellular $\mathrm{Ca}^{2+}$-handling in transgenic muscle cells (Steeghs et al. 1997). In line with earlier findings that CK is crucially involved in local ATP regeneration in the vicinity of the SR $\mathrm{Ca}^{2+}$-ATPase pump (Rossi et al. 1990), it was shown with $\mathrm{CK}$ knockout mice that the $\mathrm{CK}$ system is indeed essential for optimal refill of the $\mathrm{SR} \mathrm{Ca}^{2+}$ store in skeletal muscle (de Groof et al. 2002). According to more recent data, CK, however, is not only important for $\mathrm{Ca}^{2+}$ cycling in muscle, but also in the brain, as shown with brain $\mathrm{CK}$ knockouts, where brain $\mathrm{Ca}^{2+}$ kinetics were affected (Streijger et al. 2010). Interestingly, Cr supplementation of myogenic cells from $\mathrm{mdx}$ dystrophic mice improves intracellular $\mathrm{Ca}^{2+}$ handling (Pulido et al. 1998) and $\mathrm{Cr}$ supplementation of athletes results in shortening of muscle relaxation times in vivo, presumably by improving SR-Ca ${ }^{2+}$-pump function and intracellular $\mathrm{Ca}^{2+}$ handling (van Leemputte et al. 1999). The fact that elevating total $\mathrm{Cr}$ concentration in muscle by $\mathrm{Cr}$ supplementation of human subjects leads to an increase in muscle force and to faster muscle relaxation and recovery after exhaustive exercise, compared with non-supplemented subjects (see below), is fully in line with the described functions of the $\mathrm{CK}$ isoforms. In addition, these data indicate that by $\mathrm{Cr}$ supplementation, the efficiency of the respective subcellular CK micro-compartments can be improved via elevation of the $\mathrm{PCr}$ pool size. Finally, as to the third, by transgenic deletion of cytosolic MM-CK the observed integrative signalling through $\mathrm{CK}$, where cellular energetics is coupled to membrane metabolic sensing, is lost (Abraham et al. 2002). This would corroborate the importance of $\mathrm{CK}$ for metabolic sensing and signalling at the plasma membrane.

\section{Brain phenotypes of CK deficiency}

Besides being expressed in all brain cells, real "hot spots" of CK expression and localization are Bergman glia and Purkinje cells in the cerebellum that are important for movement coordination and control, as well as neuronal cells in the hippocampus, where learning and memory functions reside, and finally epithelial cells in the choroid plexus that are rich in ATP-dependent pumps for homeostasis of ions and metabolites between the ventricular fluid/ brain interface (Wallimann and Hemmer 1994; Kaldis et al. 1996a). Accordingly, brain CK knockouts that present with permanently reduced body weight, as well as with altered brain morphology, display altered behaviour, e.g. low nestbuilding activity, less exploratory activity, less grooming, etc. and neurological difficulties in spatial learning and memory functions (Jost CR et al. 2002; in 't Zandt et al. 2004; Streijger et al. 2005).

Recent data also show that the same animals present with problems concerning thermoregulation, eventually succumbing to a sudden and severe drop in body temperature (Streijger et al. 2009). With respect to the involvement of $\mathrm{CK}$ in thermoregulation, it is interesting to observe that $\mathrm{Cr}$ supplementation in endurance athletes improved their performance during exhausting exercise under hot conditions. That is, in responders, whose muscle total $\mathrm{Cr}$ increased during supplementation, rectal temperature and heart rate lowered and peripheral key modulators and indices for the brain neurotransmitters, serotonin and dopamine, were influenced. The subjects in the $\mathrm{Cr}$ group reacted with reduced effort perception and completed the endurance task more easily compared to controls (Hadjicharalambous et al. 2008). At the same time, $\mathrm{Cr}$ reduced 
inflammatory and muscle soreness markers after a $30 \mathrm{~km}$ race (Santos et al. 2004).

Ablation of the genes for brain-type B-CK and ubiquitous mtCK in mice also leads to frequency-dependent hearing loss and problems with vestibular functions (Shin et al. 2007), which is in line with the very high concentrations of CK found in the respective cellular structures of the inner ear. Interestingly, $\mathrm{Cr}$ supplementation significantly attenuated noise-induced hearing loss (Minami et al. 2007). Finally, brain CK knockout has demonstrated the importance of $\mathrm{CK}$ for the energetics of bone metabolism and osteoclast function for bone resorption (Chang et al. 2008). This complements earlier results concerning the expression of $\mathrm{CK}$ in osteoblasts and the beneficial action of $\mathrm{Cr}$ on survival, differentiation and mineralization of osteoblasts in culture (Gerber et al. 2005), as well as with the stimulating effects of $\mathrm{Cr}$ on collagen type I synthesis and osteoprotegerin secretion of healthy and osteoporotic human osteoblasts (Gerber et al. 2008).

Thus, it seems obvious that CK takes over specific functions in almost every cell of the body, except for liver, where under normal healthy conditions no CK is expressed (Wallimann and Hemmer 1994). Surprisingly, after the first brain CK knockout transgenic mice became available, it took almost 10 years to figure out some of the most prominent phenotypes of this type of transgenic mice. Probably, it will take another decade still to discover the more subtle phenotypic changes, gone unnoticed, which are caused by brain-type CK ablation.

\section{Creatine-nutritional constituent and supplementation}

Pleiotropic effects of creatine

Abrogation of CK enzymes in transgenic mice (see above) or depletion of the substrate $\mathrm{Cr}$ in $\mathrm{Cr}$-analogue-fed (GPA) animals, respectively, both show muscle phenotypes with similar functional deficits (Mekhfi et al. 1990; Wyss and Wallimann 1994; O'Gorman et al. 1996, 1997b; Steeghs et al. 1997, 1998). The affected functions, such as the development of muscle force and muscle relaxation, including intracellular $\mathrm{Ca}^{2+}$ handling, can be enhanced in wild-type animals, as well as in humans, by $\mathrm{Cr}$ supplementation (Kraemer and Volek 1999; van Leemputte et al. 1999). These mostly energy-related ergogenic effects of $\mathrm{Cr}$ in sports, based on the seminal work by Harris and Greenhaff in the early nineties (Harris et al. 1992; Greenhaff et al. 1993), are well known and in the meantime widely accepted (Kamber et al. 1999). The same holds true for the effects of $\mathrm{Cr}$ for rehabilitation (Hespel et al. 2001; Johnston et al. 2009) (Table 1). However, a number of potentially beneficial effects of $\mathrm{Cr}$, which are not directly related to enhancement of cellular energetics, have emerged, for example the protective effects of $\mathrm{Cr}$ on mitochondrial permeability transition pore opening (O’Gorman et al. 1997a; Dolder et al. 2003), an early event in apoptosis, or the antioxidant effects of $\mathrm{Cr}$, as well as the interference of $\mathrm{Cr}$ with cell signalling affecting the expression of muscle transcriptional factors (Hespel et al. 2001; Hespel and Derave 2007; Deldicque et al. 2008) or activating important signalling pathways such a p38 Akt/PKB (Hespel et al. 2001; Deldicque et al. 2007; Hespel and Derave 2007; Deldicque et al. 2008) or AMPK (Ceddia and Sweeney 2004) (Table 1).

Such beneficial effects of $\mathrm{Cr}$ may also alleviate toxic drug effects that target bioenergetics and mitochondria, such as the anti-cancer drug doxorubicin (Tokarska-Schlattner et al. 2002, 2006). Doxorubicin accumulates in mitochondria and affects their functions including inhibition of CK isoforms (Tokarska-Schlattner et al. 2002; Tokarska-Schlattner et al. 2005b, 2007). In an animal study, $\mathrm{Cr}$ supplementation in combination with vitamins was able to increase survival of doxorubicin-treated rats (Santos et al. 2007).

The pleiotropic effects of $\mathrm{Cr}$ on muscle growth and muscle performance have been documented in more than 400 publications to date. Cr has a scientifically unambiguously proven record of being a truly ergogenic nutritional supplement that reaches the target organs, elevates muscle total $\mathrm{Cr}$ and $\mathrm{PCr}$ pools, leads to an increase in muscle mass and elevates muscle performance in a number of sports (for reviews, see the position stands of the International Society of Sports Nutrition: Buford et al. 2007; Kerksick et al. 2008). The effects of $\mathrm{Cr}$ are most beneficial for high-intensity intermittent exercise (Kraemer and Volek 1999) but positive effects of Cr have also been noted for better fatigue resistance (Rawson et al. 2011) and for improved recovery after heavy exercise (Yquel et al. 2002). It has also been realized that $\mathrm{Cr}$ could alleviate or spare muscle damage and inflammation caused by excessive endurance performance experienced in an ironman competition (Bassit et al. 2008; see also Table 1). It is important to note that the mostly anecdotal side effects of $\mathrm{Cr}$ supplementation that are reported, e.g. via internet can be dismissed on the basis of solid scientific evidence, even if $\mathrm{Cr}$ is taken for extended periods of time (i.e. years), (Kreider et al. 2003; Francaux and Poortmans 2006; Persky and Rawson 2007; Bender et al. 2008a). However, the most relevant issue with respect to potential side effects of $\mathrm{Cr}$, namely the chemical purity of the $\mathrm{Cr}$ used, is definitely an issue (Pischel and Gastner 2007). Many of the pleiotropic effects of $\mathrm{Cr}$ for sports, health and disease are discussed in detail in this volume. Here, we would like to point out some potentially important new applications of $\mathrm{Cr}$ supplementation and their potential 
socio-economic implications for humans and for the global ecosystem.

Creatine supplementation for normal healthy people?

The protective effects of $\mathrm{Cr}$ as an adjuvant therapeutic intervention in disease states, such as neuromuscular, neuro-degenerative diseases, as well as muscle- and neurorehabilitation, have been recently reviewed in a special volume of "Subcellular Biochemistry" ("Creatine and Creatine Kinase in Health and Disease", edited by G. Salomons and M. Wyss). In particular, the neuroprotective role of $\mathrm{Cr}$ that is relevant to a number of neuromuscular and neuro-degenerative diseases is well documented (Matthews et al. 1998; Klivenyi et al. 1999; Brewer and Wallimann 2000; Wyss and Kaddurah-Daouk 2000; Baker and Tarnopolsky 2003; Andres et al. 2005a, b; Brosnan and Brosnan 2007; Rodriguez et al. 2007; Tarnopolsky 2007; Adhihetty and Beal 2008; Andres et al. 2008; Valastro et al. 2009; Gualano et al. 2010).

Little has been mentioned so far of the potential benefits of $\mathrm{Cr}$ supplementation for normal healthy people. In a placebo-controlled, randomized animal study, it was shown in fact that life-long $\mathrm{Cr}$ supplementation, even at very high daily dosage, is of significant benefit to life expectancy and most importantly also for life quality of normal healthy mice (Bender et al. 2008a). In a recent study with human subjects, glucose tolerance in healthy sedentary males undergoing aerobic training was improved by $\mathrm{Cr}$ supplementation. Thus, a change in life-style together with intake of $\mathrm{Cr}$ may prevent or delay the onset of health problems, such as type- 2 diabetes, obesity and metabolic syndrome (Gualano et al. 2008a).

Cr supplementation, in conjunction with exercise, was shown to improve muscle performance in elderly men and postmenopausal women (Gotshalk et al. 2002, 2008), as well as to increase bone mineral density in healthy elderly men (Chilibeck et al. 2005). This is in line with the findings that $\mathrm{Cr}$ increases survival, metabolic activity, as well as mineralization of cultured osteoblast cells in vitro (Gerber et al. 2005). Thus, Cr may not only be beneficial for muscle but also for bone health of normal healthy people. It is entirely conceivable that $\mathrm{Cr}$ supplementation could alleviate or prevent osteopenia and/or osteoporosis of postmenopausal women (Gerber et al. 2005, 2008), as Cr has been shown to stimulate collagen type I synthesis and secretion of osteoprotegerin in human bone cells derived from osteopenic subjects (Gerber et al. 2008).

Positive effects of $\mathrm{Cr}$ supplementation on memory, learning and mental performance (Rae et al. 2003), as well as on cognitive performance, have been demonstrated (McMorris et al. 2007), and a reduction of mental fatigue by $\mathrm{Cr}$ was also shown (Watanabe et al. 2002).
Creatine for the elderly?

A simple and inexpensive intervention, a daily supplementation with 2-5 g of chemically pure $\mathrm{Cr}$ for healthy adults and most importantly for senior and elderly people (Gotshalk et al. 2002, 2008), is likely to contribute as a preventive measure to muscle, bone and brain health, potentially saving billions of dollars otherwise spent for rehabilitation measures following accidents (Hespel and Derave 2007; Dalbo et al. 2009). Cr supplementation seems especially relevant for elderly, who often eat much less or no meat at all and thus likely have low tissue $\mathrm{Cr}$ levels, as limited data from vegans and vegetarians indicates (Burke et al. 2003; Watt et al. 2004). Recent nutritional recommendations by the US Society for Sarcopenia, Cachexia and Wasting Disease proposed Cr supplementation together with other measures for the management of sarcopenia (age-dependent progressive muscle loss) which is prevalent among the elderly (Morley et al. 2010). Interestingly, 2 weeks of $4 \times 5 \mathrm{~g}$ of $\mathrm{Cr}$ daily improved cognitive performance in the elderly (McMorris et al. 2007). With respect to the possible beneficial effects of $\mathrm{Cr}$ supplementation that have been discussed for elderly (Dalbo et al. 2009), it is important to note that Cr acts as an osmolyte. Since $\mathrm{Cr}$ is taken up by the osmotically active sodium and chloride dependent CRT, concomitant import of $\mathrm{NaCl}$ into the target cells may lead to at least a temporary increase in the intracellular water content (Ziegenfuss et al. 1998). Hydration is an important physiological parameter in humans that gradually decreases with age (Aloia et al. 1998). However, in order to substantiate these preliminary results, many highly relevant to disease prevention and potentially with significant socio-economical health benefits, multi-centre epidemiological studies involving hundreds or thousands of subjects over prolonged periods of time would be necessary. Such studies would be expensive undertakings. However, as $\mathrm{Cr}$ promises only negligible financial returns to pharmaceutical companies, such studies would most likely have to be funded by government agencies.

Creatine as a prominent nutritional constituent for man since prehistoric times

Concerning possible health benefits for healthy people, a legitimate question that may be asked is whether modern man, due to greatly changed eating habits, is justified in supplementing the diet with additional $\mathrm{Cr}$ particularly when this can be synthesised endogenously and obtained through a balanced meat and fish diet. To possibly answer this question we need to examine early hominid nutrition. A recent archaeological survey in Ethiopia brought to light stone-tool inflicted cut and percussion marks on ungulate 
bones that were dated to older than 3.39 million years. These, the oldest findings of this kind, after careful microscopic examination were identified as being the result of early hominid stone tools used for removing flesh from bones and for retrieving bone marrow (McPherron et al. 2010). These findings indicate that Australopithecus afarensis already practised butchery of large animals and consumed meat some 3.4 million years ago.

Humans have clearly evolved as carnivores/omnivores, ingesting large quantities of meat and fish, and thus necessarily also $\mathrm{Cr}$, as a significant part of their diet (Broadhurst et al. 1998; Richards 2002). There is evidence that evolutionarily human brain development and growth were strongly dependent on the availability of high-quality food, such as meat and/or fish, representing nutritionally rich sources of protein, fatty acids, vitamins and minerals (Milton 2003) and incidentally also of Cr. Evidence from isotopic analysis of skeletons of Neanderthals and modern Palaeolithic and Mesolithic humans highlights the importance of meat and fish in the hominid diet (Richards 2002). When successful at hunting or fishing, these hominids as true carnivores/omnivores, most likely devoured more than $1-2 \mathrm{~kg}$ of meat or fish per day during prolonged periods of time during the year, ingesting at least 5-10 g or more of Cr daily. The combination of high-quality diet and the higher proportion of maternal daily energy budget invested in the growing embryo during pregnancy of prehistoric women, would additionally have allowed for greater body weight as well as larger brain size (encephalization) relative to body weight of the infant at birth, compared with other primates (Ulijaszek 2002; Carlson and Kingston 2007). With respect to $\mathrm{Cr}$, it is known that endogenous synthesis of $\mathrm{Cr}$ is energetically costly in terms of methyl-group equivalents. Carnivores/omnivores ingesting large amounts of $\mathrm{Cr}$ thus spare a significant proportion of the energy needed for acquisition of reactive methyl group equivalents in the form of $S$-adenosyl-L-methionine (AdoMet) that can be used for other anabolic synthetic pathways (Brosnan et al. 2007a, b).

It, therefore, seems that the evolutionary path of hominid development is tightly linked to food quality, e.g. to ingesting large amounts of meat and fish and concomitantly also of $\mathrm{Cr}$. One might surmise from this that $\mathrm{Cr}$ supplementation should also belong to the nutritional requirements of modern man, depending on how much meat and/ or fish is actually ingested daily. Depending on the cultural and economic background, the present daily meat consumption varies from zero (vegans) to approximately $150 \mathrm{~g}$ (Switzerland) or 250-300 g (USA, Australia) of meat/ person/day (numbers include not only fresh but also processed meat that is known to contain much less $\mathrm{Cr}$ than fresh meat, or even none at all). These numbers correspond to a daily $\mathrm{Cr}$ consumption per person from zero to about $0.75-1.5 \mathrm{~g}$ and are clearly at the lower end of daily alimentary requirements for $\mathrm{Cr}$ that may be in the order of 2-4 g/person/day (see European Food Safety Authority web site: http://www.efsa.europa.eu/EFSA/efsa_locale1178620753812_1178620761727.htm).

Finally, the fact that in most people who ingest extra $\mathrm{Cr}$ the total $\mathrm{Cr}$ pool size $(\mathrm{Cr}+\mathrm{PCr})$ in muscle is elevated by 5-20\% indicates that in these the $\mathrm{Cr}$ pools are not saturated. This alone could be taken as an argument that even normal healthy people should supplement with $\mathrm{Cr}$. The fact that meat consumption is recommended to be lowered globally for health (cf. high cholesterol, etc.) and ecological reasons lends additional support to the argument for $\mathrm{Cr}$ supplementation of the diet.

Foetal creatine metabolism and supply during pregnancy

Using a special precocial mouse strain, the spiny mouse (Acomys cahirinus) with a longer pregnancy than that of normal mice, closely resembling human pregnancy, it was convincingly shown that $\mathrm{Cr}$ supplementation protects the brain of the mouse pups in vivo against hypoxia and thus significantly enhances survival of the offspring (Ireland et al. 2008). This corroborates earlier findings that $\mathrm{Cr}$ protects the brain of newborn rats against hypoxia (Adcock et al. 2002) or of adult mice in a model of stroke (Prass et al. 2007). Also, $\mathrm{Cr}$ displayed astonishingly positive effects in traumatic brain injury in animals (Sullivan et al. 2000; Hausmann et al. 2002), as well as in children and adolescent patients (Sakellaris et al. 2006). Maternal Cr supplementation from mid-pregnancy onwards has most recently been shown to protect the diaphragm of the newborn spiny mouse from intra-partum hypoxia-induced damage (Cannata et al. 2010).

What is new in the spiny mouse study is the fact that pregnant dams were fed $\mathrm{Cr}$. This orally fed $\mathrm{Cr}$ is actively transported into the foetus via placental CRT (Ireland et al. 2009). Cr supplementation of the pregnant dam leads to an enhancement of total Cr levels in most organs, not only of the mother but also of the embryo, including the brain and thus protects the precocial mouse pups from episodes of hypoxia during a simulated hypoxic birth (Ireland et al. 2008; Cannata et al. 2010). These are important findings indicating that $\mathrm{Cr}$ supplementation during pregnancy may be a general protective measure to lower the incidence of brain damage and enhance survival also of human babies that go through periods of anoxia during birth or are at high-risk for an ischemic/anoxic birth to start with. Thus, it is entirely conceivable that the protective effects of $\mathrm{Cr}$ that are observed with experimental animals will also hold true for humans. 
In line with this hypothesis is the fact that endogenous $\mathrm{Cr}$ synthesis in the spiny mouse foetus gradually develops, but only reaches a mature level some time after birth (Ireland et al. 2009). The placenta expresses relatively high amounts of $\mathrm{Cr}$ transporter (CRT) and the expression of CRT in the placenta is high during the entire pregnancy and increases even more before birth (Ireland et al. 2009). This indicates that a significant part of embryonic $\mathrm{Cr}$ is taken up via the placenta and endogenous $\mathrm{Cr}$ synthesis in the foetus is not yet fully established. Thus, it can be concluded that the spiny mouse foetus depends on $\mathrm{Cr}$ delivered by the mother via her placenta. Although $\mathrm{Cr}$ is basically free of significant side effects, the dosage of $\mathrm{Cr}$, used in the experiments with spiny mice described above, was very high with $5 \%,(\mathrm{w} / \mathrm{w})$ in the food. This amounts, depending on how much food a pregnant mouse consumes, to an equivalent of 20-50 $\mathrm{g}$ of $\mathrm{Cr}$ or more per day for an adult human. This, on the other hand, demonstrates that $\mathrm{Cr}$ is safe also at high dosages, even for the foetus, which is in line with a study using $\mathrm{Cr}$ supplementation for premature babies in a clinical set-up, where no serious side effects of $\mathrm{Cr}$ had been observed in preterm babies (Bohnhorst et al. 2004).

In addition to the obvious benefits of $\mathrm{Cr}$ for the baby, $\mathrm{Cr}$ supplementation of the mother during pregnancy could additionally be of benefit for the build-up of a strong uterus during the third trimester, when the uterus energetically matures by implementing the CK system (Dawson and Wray 1985; Clark et al. 1993; Clark 1994; Wallimann and Hemmer 1994). This could help to ease birthing, which largely depends on the energy charge of uterine smooth muscle and thus also of the PCr pool size (Kumar et al. 1962), to develop sufficient muscle force for the expulsion of the embryo. Therefore, it may be legitimate to propose that $\mathrm{Cr}$ supplementation should be a standard regimen during pregnancy, as well as after birth, both for the pregnant and lactating mother, as well as for the baby. This would favour healthy brain development of the embryo and baby, as it is obvious that $\mathrm{Cr}$-deficient patients suffer from severe developmental delay with accompanying mental retardation (Schulze 2003).

\section{Creatine as natural constituent of mother's milk}

Human colostrums and milk contain significant concentrations of $\mathrm{Cr}$, in the range of $0.2 \mathrm{mM}$ (Hulsemann et al. 1987; Peral et al. 2005). The same is true for cow and sow milk with approximately $0.8 \mathrm{mM} \mathrm{Cr}$ (Sheffy et al. 1952; Hulsemann et al. 1987; Peral et al. 2005). Interestingly, in a detailed study on sow colostrums and milk throughout lactation and weaning, both $\mathrm{Cr}$ and $\mathrm{PCr}$ were identified at up to 1.5 and $1.2 \mathrm{mM}$ concentrations, respectively (Kennaugh et al. 1997). It seems that $\mathrm{Cr}$ values can vary significantly, depending on the analytical techniques used. In addition, the variation found in the absolute $\mathrm{Cr}$ values and the $\mathrm{Cr} / \mathrm{Crn}$ ratio may indicate that not always fresh milk was analysed. Using non-destructive NMR methods and spectral peak assignments, however, a prominent proton NMR peak was identified as $\mathrm{Cr}$ in bovine milk ( $\mathrm{Hu}$ et al. 2004), thus leaving no doubt that $\mathrm{Cr}$ is a genuine chemical constituent in fresh milk. It would be of importance to investigate in detail whether and how nutrition would influence the total $\mathrm{Cr}$ content in mother's milk.

A 3- to 4-month-old baby of $5 \mathrm{~kg}$ consumes approximately $800 \mathrm{ml}$ milk per day from the mother at $0.2 \mathrm{mM} \mathrm{Cr}$, or from cow milk, at $0.8 \mathrm{mM} \mathrm{Cr}$ (Hulsemann et al. 1987), amounting to a $\mathrm{Cr}$ ingestion of 4 or $16 \mathrm{mg} \mathrm{Cr} / \mathrm{kg}$ body weight per day, respectively, which translates into approximately 0.3 or $1.2 \mathrm{~g}$ of $\mathrm{Cr}$ per day, respectively, for an adult person. Considering the fact that a significant amount of creatinine (25\% in cow milk and more than $50 \%$ in human milk) was also found that may have arisen from $\mathrm{Cr}$ break-down during pasteurization of the milk, one can assume the above values to be lower-limit estimates, such that the actual $\mathrm{Cr}$ in fresh milk and, concomitantly, also the $\mathrm{Cr}$ intake by infants would be higher by a factor of 2-3 if really fresh milk were consumed.

Creatine supplementation of the mother during pregnancy, and of baby formulas and infant nutrition?

$\mathrm{Cr}$ is secreted by the mammary gland during lactation and has been shown to be absolutely required for normal brain development and brain function (see Wyss and Schulze 2002). According to recent data from rats, the rat mammary gland of dams does not synthesize the $\mathrm{Cr}$ to be secreted but is extracted from the circulation (Lamarre et al. 2010). Since there was no increase in endogenous $\mathrm{Cr}$ synthesis in the dams, this required an increase for the lactating mother of approximately $50 \%$ in alimentary $\mathrm{Cr}$ above the normal daily requirement. In rats, this is largely compensated by hyperphagia, as normal rat feed contains $\mathrm{Cr}$ that is introduced by dried meat and fish products (Lamarre et al. 2010). This suggests that pregnant, and even more so lactating mothers, who remain vegans or vegetarians during pregnancy and lactation, may suffer from an inadequate supply of $\mathrm{Cr}$, which in turn may not be favourable for the development of the foetus and infant when nursing.

In the above work, it was further shown that while $\mathrm{Cr}$ is substantially accumulated in the growing pups, only $12 \%$ of this was obtained from the mother's milk (Lamarre et al. 2010). Thus, the relatively high need for $\mathrm{Cr}$ in the rat pups clearly places a metabolic burden on them, since, as mentioned earlier, endogenous $\mathrm{Cr}$ synthesis is energy costly and may use as much as $40 \%$ of the total SAM 
available for trans-methylation reactions (Brosnan and Brosnan 2007; Brosnan et al. 2007a, b). If this is also true for humans (Mudd et al. 2007), the legitimate question arises, as to whether supplementing lactating women with $\mathrm{Cr}$ and thus have them secrete more $\mathrm{Cr}$ into their mothers milk may relieve some of the metabolic burden of energycostly endogenous $\mathrm{Cr}$ synthesis by the baby. The same would hold true with respect to supplementing baby food and infant nutrition with $\mathrm{Cr}$ in non-nursing mothers or after weaning.

Except for soy-based baby milk, which is devoid of $\mathrm{Cr}$, most of the baby formulas and follow-up baby nutrition preparations were found to contain $\mathrm{Cr}$ and $\mathrm{Crn}$ in a similar concentration range $(0.3$ and $0.1 \mathrm{mM}$, respectively) as mother's milk, although with significant variations (Hulsemann et al. 1987). Thus, pending more thorough investigations, it may turn out to be advisable to control and eventually supplement not only purely vegetarian soy-based baby food, but also all infant nutrition products, with $\mathrm{Cr}$. Interesting in this context is the fact that it was already noted in 1913 that "the increase in body weight of a baby after birth was roughly proportional to the $\mathrm{Cr}$ excreted in the urine by the respective mothers and that the excreted $\mathrm{Cr} / \mathrm{Crn}$ ratio of the urine increased proportionally with mammary gland activity" (Mellanby 1913). Thus Cr, be it delivered via mothers milk or supplemented externally, seems generally beneficial for growth and development of the infant.

Since $\mathrm{Cr}$ is definitely an important constituent in milk of mammals, including humans, it is hard to understand that there still exist baby formulas and early infant nutrition products, especially products based entirely on soy-bean, which do not contain any or only very little $\mathrm{Cr}$. Changing this situation should be a high priority of International and European Child Nutrition Advisory Boards, and this should be an important focus of $\mathrm{Cr}$ research during the coming years. The socio-economic benefit of this and other $\mathrm{Cr}$ supplementation applications, e.g. for general skeletomuscular- (Tarnopolsky 2007) and neuro-rehabilitation (Sakellaris et al. 2006) seems obvious since every infant spared from irreversible brain damage caused for example by ischemia/anoxia during a difficult birth (Adcock et al. 2002; Ireland et al. 2008, 2009; Cannata et al. 2010) is beyond reckoning, not to speak of the relief from suffering. The objection that $\mathrm{Cr}$ could have side effects on human babies and infants has no scientific foundation. In a recent clinical study with premature infants, who were given $200 \mathrm{mg}$ of $\mathrm{Cr}$ per $\mathrm{kg}$ body weight per day for 2 weeks, a dose corresponding to $14 \mathrm{~g}$ of $\mathrm{Cr}$ per day for an adult person of $70 \mathrm{~kg}$, the treatment was well tolerated and no side effects were noted (Bohnhorst et al. 2004). However, there is an urgent need of clinically controlled studies in the field to determine a physiologically acceptable $\mathrm{Cr}$ dose for use with infants.
Children with a so-called Cr-deficiency syndrome, who have genetic defects either in one of the enzymes for endogenous $\mathrm{Cr}$ synthesis (AGAT or GAMT), or in the CRT, present with severe neurological symptoms, such as developmental and speech delay, mental retardation, autism and epilepsy (Schulze 2003), which is largely due to the complete absence of $\mathrm{Cr}$ in brain tissue. This emphasises the importance of $\mathrm{Cr}$ for normal brain development and function (Newmeyer et al. 2005) and, by implication, advocates the adoption of $\mathrm{Cr}$ supplementation for pregnant women, as well as for preterm babies and infants. It seems of utmost importance that $\mathrm{Cr}$ in infant food is recognized as an essential component of human nutrition and that its content in infant formulas should be mandatorily regulated and controlled.

Finally, the clinical tests (from urine and blood) for Cr-deficiency should be mandatory for all newborns. By this strategy, infants with treatable Cr-deficiencies (in AGAT or GAMT, but not in CRT) could be helped to lead a normal life.

Creatine supplementation of parenteral nutrition?

Individuals, who are supported in intensive care units (ICU), as well as severely ill patients with a variety of disease states, e.g. cancer patients with cachexia, fully depend on parenteral food which ideally should include supplementary $\mathrm{Cr}$ if needs are to be met. Unfortunately, $\mathrm{Cr}$ has not yet been recognized as a nutrient to be included in parenteral food. In this way, atrophy of muscles, particularly intra-costal muscles and diaphragm, could be lessened in IUC patients that are supported by artificial ventilation. The longer artificial ventilation is implemented, the more difficulties such patients experience in resuming independent breathing. Since $\mathrm{Cr}$ has been shown to significantly alleviate muscle disuse atrophy (Johnston et al. 2009), it is to be expected that resumption of breathing and rehabilitation of ICU patients may also be positively influenced by Cr. The same, of course, holds true for severely ill patients presenting with cachexia, as often occurs for cancer patients. Parenteral supplementation with $\mathrm{Cr}$ would help to prevent the physiological sequelae of $\mathrm{Cr}$ depletion to be expected in such patients (Wyss and Wallimann 1994).

Creatine for dialysis patients?

As pointed out earlier, $\mathrm{Cr}$ is not toxic to the kidney but rather is important for kidney function itself, since the CK/ PCr system supports ion-pumps and metabolite transporters in this organ that are responsible for ion balance and resorption of metabolites from the urine. Patients with chronic renal failure (CRF) undergoing dialysis, who for obvious reasons are advised to restrict meat consumption, 
may present after a certain time with an altered skeletal and cardiac muscle energy metabolism, being low or deficient in $\mathrm{Cr}$ and showing a low PCr/ATP ratio (Pastoris et al. 1997; Tagami et al. 1998; Ogimoto et al. 2003). It is known that these patients lose muscle mass, become weaker and experience chronic fatigue. For these reasons, supplementation of dialysis patients with $\mathrm{Cr}$ might be viewed as an adjuvant therapy that should be implemented for counteracting some of the side effects of prolonged dialysis. An elegant method for $\mathrm{Cr}$ supplementation of this group of patients, undergoing either peritoneal or haemodialysis, would be to add appropriate amounts of Cr directly into the dialysis fluid. This would ease compliance and spare the patients to have to orally ingest yet another powder besides phosphate and calcium binders, etc. In the only study so with dialysis patients, involving the very limited number of five patients, oral $\mathrm{Cr}$ supplementation reduced spastic muscle cramps, a problem often observed in these patients (Chang et al. 2002).

Creatine as feed additive for animal nutrition, growing life stock and aquaculture?

Endogenous synthesis of $\mathrm{Cr}$ is energy-costly and consumes some $40 \%$ of the SAM available for methylation reactions (Brosnan et al. 2007a, b, 2009). In addition, the three amino acids needed for $\mathrm{Cr}$ synthesis, arginine, glycine and methionine are valuable and some are 'physiologically' expensive. By including chemically synthesised $\mathrm{Cr}$ in a pure form in animal feeds, these amino acids would be spared for protein synthesis and growth. This holds true also for processed and dry pet food, which compared with fresh meat and offal contains very little $\mathrm{Cr}$ (Harris et al. 1997), such that supplementation with $\mathrm{Cr}$ of pet food would make sense.

Chickens fed during a growing period of 41 days with an entirely vegetable soy-based feed, to which $0.2 \%$ w/w of pure $\mathrm{Cr}$ was added, show a $4 \%$ greater body weight gain compared with chickens fed with normal meat- and fishmeal containing feed. In addition, feed consumption in the Cr group decreased by $2-3 \%$ and the weight gain was shown to be due to growth of lean muscle mass (Pfirter and Wallimann, unpublished data). Thus, Cr may have significant potential as an additive for animal feed, replacing millions of tons of meat- and fish-meal for animals, as well as for fish aquaculture. On a global scale, this could help with problems of world hunger and the prevention of overfishing of oceans for fish-meal production. Interestingly $\mathrm{Cr}$ supplementation of Drosophila melanogaster, known to express arginine kinase (AK) instead of CK (Wallimann and Eppenberger 1973), protects these flies from oxidative stress caused by exposure to rotenone, a potent mitochondrial toxin, and paraquat, a potent herbicidal redox cycler, that both generate ROS (Hosamani et al. 2010). Since these insects are not able to phosphorylate $\mathrm{Cr}$ into $\mathrm{PCr}$, the protective effects of $\mathrm{Cr}$ observed cannot be due to improved cellular energetics, but are more likely related to anti-oxidant and/or anti-apoptotic effects of this guanidino compound. Thus $\mathrm{Cr}$ may be added to animal feed as a protectant also against environmental oxidative and toxic stress.

Acknowledgments Work from the authors cited in this review has been supported by the Swiss National Science Foundation, ETH Zürich, French "Agence Nationale de Recherche" ("chaire d'excellence" given to US), the University Joseph Fourier "Fonds d'intervention", an EC Marie Curie Intraeuropean Fellowship (ANTHRAWES contract 041870 to MTS), an EC Marie Curie Reintegration Grant (ANTHRAPLUS contract 249202 to MTS), and the Swiss foundations Zürcher Krebsliga, Zentralschweizer Krebsstiftung, and Wolfermann-Nägeli Stiftung. T. W. would like to thank Prof. emeritus Hans M. Eppenberger for the occasion to start these $\mathrm{CK}$ and Cr-related projects in his former laboratory and for support. We would like to dedicate this essay to all former members of the Wallimann and Schlattner research groups, who contributed over the past 30 years in a significant way to elucidate the localization, structure, function and regulation of $\mathrm{CK}$ and the effects of $\mathrm{Cr}$ in vitro and in vivo. It is indeed very gratifying for basic researchers to see that some of the ideas on Cr supplementation are slowly finding their way into the clinics and that patients may benefit from a simple and safe intervention like $\mathrm{Cr}$. We also express our gratitude to all external national and international collaborators, who often engaged in mutual long-term collaborations without many questions asked and to whom we developed personal friendships.

Open Access This article is distributed under the terms of the Creative Commons Attribution Noncommercial License which permits any noncommercial use, distribution, and reproduction in any medium, provided the original author(s) and source are credited.

\section{Appendix}

For a general update in the field, see the recently published books:

- Saks VA (ed) (2007) Molecular systems bioenergetics: energy for life. Wiley-VCH, Weinheim.

- Salomons GS, Wyss M (eds) (2007) Creatine and creatine kinase in health and disease. Subcellular Biochemistry, vol 46. Springer, Dordrecht.

- Vial C (ed), Uversky VN (series ed) (2006) Creatine kinase-biochemistry, physiology, structure and function. Nova Science Publishers, New York.

Note added in proof After this review had been submitted some most recent clinically relevant publications have appeared which are fully supporting the views on the multiple beneficial actions of creatine supplementation expressed in the review presented here. From the number of most recent publications in the field, plus those appearing in the present special volume of the Journal "Amino 
Acids", it seems that both basic and especially also clincial research on the pleiotropic functions of creatine is gaining momentum again. Some of these publications are listed as references below.

Benton D, Donohoe R (2011) The influence of creatine supplementation on the cognitive functioning of vegetarians and omnivores. Br J Nutr 105:1100-1105

Candow DG (2011) Sarcopenia: current theories and the potential beneficial effect of creatine application strategies. Biogerontology. [Epub ahead of print Mar 4]. doi:10.1007/s10522-011-9327-6

Cook CJ, Crewther BT, Kilduff LP, Drawer S, Gaviglio CM (2011) Skill execution and sleep deprivation: effects of acute caffeine or creatine supplementation - a randomized placebocontrolled trial. J Int Soc Sports Nutr 8:2

Deminice R, Vannucchi H, Simoes-Ambrosio LM, Jordao AA (2011) Creatine supplementation reduces increased homocysteine concentration induced by acute exercise in rats. Eur J Appl Physiol. [Epub ahead of print Mar 11]. doi:10.1007/s00421-011-1891-6

Gualano B, de Salles Painelli V, Roschel H, Lugaresi R, Dorea E, Artioli GG, Lima FR, da Silva ME, Cunha MR, Seguro AC, Shimizu MH, Otaduy MC, Sapienza MT, da Costa Leite C, Bonfa E, Lancha Junior AH (2010) Creatine supplementation does not impair kidney function in type 2 diabetic patients: a randomized, double-blind, placebo-controlled, clinical trial. Eur J Appl Physiol. [Epub ahead of print Oct 26]. doi:10.1007/s00421-010-1676-3

Gualano B, de Salles Painneli V, Roschel H, Artioli GG, Jr., MN, Lucia de Sa Pinto A, Rossi daSilva ME, Cunha MR, Otaduy MC, da Costa Leite C, Ferreira JC, Pereira RM, Brum PC, Bonfa E, Lancha AHJ (2010) Creatine in Type 2 Diabetes: A Randomized, DoubleBlind, Placebo-Controlled Trial. Med Sci Sports Exerc. [Epub ahead of print Sep 24]. doi:10.1249/MSS.0b013e3181fcee7d

Neves M, Jr., Gualano B, Roschel H, Fuller R, Benatti FB, de Sa Pinto AL, Lima FR, Pereira RM, Lancha AH, Jr., Bonfa E (2011) Beneficial Effect of Creatine Supplementation in Knee Osteoarthritis. Med Sci Sports Exerc. [Epub ahead of print Feb 8]. doi:10.1249/ MSS.0b013e3182118592

Rawson ES, Stec MJ, Frederickson SJ, Miles MP (2011) Lowdose creatine supplementation enhances fatigue resistance in the absence of weight gain. Nutrition 27:451-455

Rawson ES, Venezia AC (2011) Use of creatine in the elderly and evidence for effects on cognitive function in young and old. Amino Acids. [Epub ahead of print Mar 11]. doi:10.1007/s00726-011-0855-9

Sanchez-Gonzalez MA, Wieder R, Kim JS, Vicil F, Figueroa A (2011) Creatine supplementation attenuates hemodynamic and arterial stiffness responses following an acute bout of isokinetic exercise. Eur J Appl Physiol. [Epub ahead of print Jan 20]. doi:10.1007/ s00421-011-1832-4

Shewmon DA, Craig JM (2010) Creatine supplementation prevents statin-induced muscle toxicity. Ann Intern Med 153:690-692.

\section{References}

Abraham MR, Selivanov VA, Hodgson DM, Pucar D, Zingman LV, Wieringa B, Dzeja PP, Alekseev AE, Terzic A (2002) Coupling of cell energetics with membrane metabolic sensing. Integrative signaling through creatine kinase phosphotransfer disrupted by M-CK gene knock-out. J Biol Chem 277:24427-24434

Adcock KH, Nedelcu J, Loenneker T, Martin E, Wallimann T, Wagner BP (2002) Neuroprotection of creatine supplementation in neonatal rats with transient cerebral hypoxia-ischemia. Dev Neurosci 24:382-388

Adhihetty PJ, Beal MF (2008) Creatine and its potential therapeutic value for targeting cellular energy impairment in neurodegenerative diseases. Neuromolecular Med 10:275-290

Alfieri RR, Bonelli MA, Cavazzoni A, Brigotti M, Fumarola C, Sestili P, Mozzoni P, De Palma G, Mutti A, Carnicelli D, Vacondio F,
Silva C, Borghetti AF, Wheeler KP, Petronini PG (2006) Creatine as a compatible osmolyte in muscle cells exposed to hypertonic stress. J Physiol 576:391-401

Aloia JF, Vaswani A, Flaster E, Ma R (1998) Relationship of body water compartments to age, race, and fat-free mass. J Lab Clin Med 132:483-490

Andres RH, Ducray AD, Perez-Bouza A, Schlattner U, Huber AW, Krebs SH, Seiler RW, Wallimann T, Widmer HR (2005a) Creatine supplementation improves dopaminergic cell survival and protects against MPP+ toxicity in an organotypic tissue culture system. Cell Transplant 14:537-550

Andres RH, Huber AW, Schlattner U, Perez-Bouza A, Krebs SH, Seiler RW, Wallimann T, Widmer HR (2005b) Effects of creatine treatment on the survival of dopaminergic neurons in cultured fetal ventral mesencephalic tissue. Neuroscience 133:701-713

Andres RH, Ducray AD, Schlattner U, Wallimann T, Widmer HR (2008) Functions and effects of creatine in the central nervous system. Brain Res Bull 76:329-343

Azzolin L, von Stockum S, Basso E, Petronilli V, Forte MA, Bernardi $P(2010)$ The mitochondrial permeability transition from yeast to mammals. FEBS Lett 584:2504-2509

Baker SK, Tarnopolsky MA (2003) Targeting cellular energy production in neurological disorders. Expert Opin Investig Drugs 12:1655-1679

Bassit RA, Curi R, Costa Rosa LF (2008) Creatine supplementation reduces plasma levels of pro-inflammatory cytokines and PGE2 after a half-ironman competition. Amino Acids 35:425-431

Bender A, Beckers J, Schneider I, Holter SM, Haack T, Ruthsatz T, Vogt-Weisenhorn DM, Becker L, Genius J, Rujescu D, Irmler M, Mijalski T, Mader M, Quintanilla-Martinez L, Fuchs H, Gailus-Durner V, de Angelis MH, Wurst W, Schmidt J, Klopstock T (2008a) Creatine improves health and survival of mice. Neurobiol Aging 29:1404-1411

Bender A, Samtleben W, Elstner M, Klopstock T (2008b) Long-term creatine supplementation is safe in aged patients with Parkinson disease. Nutr Res 28:172-178

Berneburg M, Gremmel T, Kurten V, Schroeder P, Hertel I, von Mikecz A, Wild S, Chen M, Declercq L, Matsui M, Ruzicka T, Krutmann J (2005) Creatine supplementation normalizes mutagenesis of mitochondrial DNA as well as functional consequences. J Invest Dermatol 125:213-220

Bertin M, Pomponi SM, Kokuhuta C, Iwasaki N, Suzuki T, Ellington WR (2007) Origin of the genes for the isoforms of creatine kinase. Gene 392:273-282

Bessman SP (1986) The physiological significance of the creatine phosphate shuttle. Adv Exp Med Biol 194:1-11

Bessman SP (1987) The creatine phosphate energy shuttle-the molecular asymmetry of a "pool". Anal Biochem 161:519-523

Bessman SP, Geiger PJ (1981) Transport of energy in muscle: the phosphorylcreatine shuttle. Science 211:448-452

Bohnhorst B, Geuting T, Peter CS, Dordelmann M, Wilken B, Poets CF (2004) Randomized, controlled trial of oral creatine supplementation (not effective) for apnea of prematurity. Pediatrics 113:e303-e307

Brdiczka DG, Zorov DB, Sheu SS (2006) Mitochondrial contact sites: their role in energy metabolism and apoptosis. Biochim Biophys Acta 1762:148-163

Brewer GJ, Wallimann TW (2000) Protective effect of the energy precursor creatine against toxicity of glutamate and beta-amyloid in rat hippocampal neurons. J Neurochem 74:1968-1978

Broadhurst CL, Cunnane SC, Crawford MA (1998) Rift Valley lake fish and shellfish provided brain-specific nutrition for early Homo. Br J Nutr 79:3-21

Brosnan JT, Brosnan ME (2007) Creatine: endogenous metabolite, dietary, and therapeutic supplement. Annu Rev Nutr 27:241-261 
Brosnan JT, da Silva R, Brosnan ME (2007a) Amino acids and the regulation of methyl balance in humans. Curr Opin Clin Nutr Metab Care 10:52-57

Brosnan ME, Edison EE, da Silva R, Brosnan JT (2007b) New insights into creatine function and synthesis. Adv Enzyme Regul 47:252-260

Brosnan JT, Wijekoon EP, Warford-Woolgar L, Trottier NL, Brosnan ME, Brunton JA, Bertolo RF (2009) Creatine synthesis is a major metabolic process in neonatal piglets and has important implications for amino acid metabolism and methyl balance. J Nutr 139:1292-1297

Buford TW, Kreider RB, Stout JR, Greenwood M, Campbell B, Spano M, Ziegenfuss T, Lopez H, Landis J, Antonio J (2007) International Society of Sports Nutrition position stand: creatine supplementation and exercise. J Int Soc Sports Nutr 4:6

Burke DG, Chilibeck PD, Parise G, Candow DG, Mahoney D, Tarnopolsky M (2003) Effect of creatine and weight training on muscle creatine and performance in vegetarians. Med Sci Sports Exerc 35:1946-1955

Cannata DJ, Ireland Z, Dickinson H, Snow RJ, Russell AP, West JM, Walker DW (2010) Maternal creatine supplementation from mid-pregnancy protects the newborn spiny mouse diaphragm from intrapartum hypoxia-induced damage. Pediatr Res 68:393-398

Canonaco F, Schlattner U, Pruett PS, Wallimann T, Sauer U (2002) Functional expression of phosphagen kinase systems confers resistance to transient stresses in Saccharomyces cerevisiae by buffering the ATP pool. J Biol Chem 277:31303-31309

Canonaco F, Schlattner U, Wallimann T, Sauer U (2003) Functional expression of arginine kinase improves recovery from $\mathrm{pH}$ stress of Escherichia coli. Biotechnol Lett 25:1013-1017

Carlson BA, Kingston JD (2007) Docosahexaenoic acid, the aquatic diet, and hominin encephalization: difficulties in establishing evolutionary links. Am J Hum Biol 19:132-141

Ceddia RB, Sweeney G (2004) Creatine supplementation increases glucose oxidation and AMPK phosphorylation and reduces lactate production in L6 rat skeletal muscle cells. J Physiol 555:409-421

Chang CT, Wu CH, Yang CW, Huang JY, Wu MS (2002) Creatine monohydrate treatment alleviates muscle cramps associated with haemodialysis. Nephrol Dial Transplant 17:1978-1981

Chang EJ, Ha J, Oerlemans F, Lee YJ, Lee SW, Ryu J, Kim HJ, Lee Y, Kim HM, Choi JY, Kim JY, Shin CS, Pak YK, Tanaka S, Wieringa B, Lee ZH, Kim HH (2008) Brain-type creatine kinase has a crucial role in osteoclast-mediated bone resorption. Nat Med 14:966-972

Chilibeck PD, Chrusch MJ, Chad KE, Shawn Davison K, Burke DG (2005) Creatine monohydrate and resistance training increase bone mineral content and density in older men. J Nutr Health Aging 9:352-353

Chung Y, Sharman R, Carlsen R, Unger SW, Larson D, Jue T (1998) Metabolic fluctuation during a muscle contraction cycle. Am J Physiol 274:C846-C852

Clark JF (1994) The creatine kinase system in smooth muscle. Mol Cell Biochem 133-134:221-232

Clark JF, Khuchua Z, Kuznetsov A, Saks VA, Ventura-Clapier R (1993) Compartmentation of creatine kinase isoenzymes in myometrium of gravid guinea-pig. J Physiol 466:553-572

Dalbo VJ, Roberts MD, Lockwood CM, Tucker PS, Kreider RB, Kerksick CM (2009) The effects of age on skeletal muscle and the phosphocreatine energy system: can creatine supplementation help older adults. Dyn Med 8:6

Dawson MJ, Wray S (1985) The effects of pregnancy and parturition on phosphorus metabolites in rat uterus studied by 31P nuclear magnetic resonance. J Physiol 368:19-31 de Groof AJ, Oerlemans FT, Jost CR, Wieringa B (2001a) Changes in glycolytic network and mitochondrial design in creatine kinasedeficient muscles. Muscle Nerve 24:1188-1196

de Groof AJ, Smeets B, Groot Koerkamp MJ, Mul AN, Janssen EE, Tabak HF, Wieringa B (2001b) Changes in mRNA expression profile underlie phenotypic adaptations in creatine kinasedeficient muscles. FEBS Lett 506:73-78 Erratum in FEBS Lett 508:163

de Groof AJ, Fransen JA, Errington RJ, Willems PH, Wieringa B, Koopman WJ (2002) The creatine kinase system is essential for optimal refill of the sarcoplasmic reticulum $\mathrm{Ca} 2+$ store in skeletal muscle. J Biol Chem 277:5275-5284

Deldicque L, Theisen D, Bertrand L, Hespel P, Hue L, Francaux M (2007) Creatine enhances differentiation of myogenic $\mathrm{C} 2 \mathrm{C} 12$ cells by activating both p38 and Akt/PKB pathways. Am J Physiol Cell Physiol 293:C1263-C1271

Deldicque L, Atherton P, Patel R, Theisen D, Nielens H, Rennie MJ, Francaux M (2008) Effects of resistance exercise with and without creatine supplementation on gene expression and cell signaling in human skeletal muscle. J Appl Physiol 104:371-378

Deminice R, Portari GV, Vannucchi H, Jordao AA (2009) Effects of creatine supplementation on homocysteine levels and lipid peroxidation in rats. Br J Nutr 102:110-116

Dillon PF, Clark JF (1990) The theory of diazymes and functional coupling of pyruvate kinase and creatine kinase. $\mathrm{J}$ Theor Biol 143:275-284

Dolder M, Walzel B, Speer O, Schlattner U, Wallimann T (2003) Inhibition of the mitochondrial permeability transition by creatine kinase substrates. Requirement for microcompartmentation. J Biol Chem 278:17760-17766

Dzeja PP, Terzic A (1998) Phosphotransfer reactions in the regulation of ATP-sensitive K+ channels. FASEB J 12:523-529

Eder M, Schlattner U, Becker A, Wallimann T, Kabsch W, Fritz-Wolf K (1999) Crystal structure of brain-type creatine kinase at $1.41 \mathrm{~A}$ resolution. Protein Sci 8:2258-2269

Eder M, Fritz-Wolf K, Kabsch W, Wallimann T, Schlattner U (2000a) Crystal structure of human ubiquitous mitochondrial creatine kinase. Proteins 39:216-225

Eder M, Stolz M, Wallimann T, Schlattner U (2000b) A conserved negatively charged cluster in the active site of creatine kinase is critical for enzymatic activity. J Biol Chem 275:27094-27099

Epand RF, Schlattner U, Wallimann T, Lacombe ML, Epand RM (2007a) Novel lipid transfer property of two mitochondrial proteins that bridge the inner and outer membranes. Biophys J 92:126-137

Epand RF, Tokarska-Schlattner M, Schlattner U, Wallimann T, Epand RM (2007b) Cardiolipin clusters and membrane domain formation induced by mitochondrial proteins. J Mol Biol 365:968-980

Eppenberger-Eberhardt M, Riesinger I, Messerli M, Schwarb P, Muller M, Eppenberger HM, Wallimann T (1991) Adult rat cardiomyocytes cultured in creatine-deficient medium display large mitochondria with paracrystalline inclusions, enriched for creatine kinase. J Cell Biol 113:289-302

Francaux M, Poortmans JR (2006) Side effects of creatine supplementation in athletes. Int J Sports Physiol Perform 1:311-323

Fritz-Wolf K, Schnyder T, Wallimann T, Kabsch W (1996) Structure of mitochondrial creatine kinase. Nature 381:341-345

Gerber I, ap Gwynn I, Alini M, Wallimann T (2005) Stimulatory effects of creatine on metabolic activity, differentiation and mineralization of primary osteoblast-like cells in monolayer and micromass cell cultures. Eur Cell Mater 10:8-22

Gerber I, Gerber H, Dora C, Uebelhart D, Wallimann T (2008) Creatine supplementation stimulates collagen type I and osteoprotegerin secretion of healthy and osteopenic primary human osteoblast-like cells in vitro. Bone 42:S21 
Gotshalk LA, Volek JS, Staron RS, Denegar CR, Hagerman FC, Kraemer WJ (2002) Creatine supplementation improves muscular performance in older men. Med Sci Sports Exerc 34:537-543

Gotshalk LA, Kraemer WJ, Mendonca MA, Vingren JL, Kenny AM, Spiering BA, Hatfield DL, Fragala MS, Volek JS (2008) Creatine supplementation improves muscular performance in older women. Eur J Appl Physiol 102:223-231

Greenhaff PL, Casey A, Short AH, Harris R, Soderlund K, Hultman E (1993) Influence of oral creatine supplementation of muscle torque during repeated bouts of maximal voluntary exercise in man. Clin Sci (Lond) 84:565-571

Grehl T, Muller K, Vorgerd M, Tegenthoff M, Malin JP, Zange J (1998) Impaired aerobic glycolysis in muscle phosphofructokinase deficiency results in biphasic post-exercise phosphocreatine recovery in 31P magnetic resonance spectroscopy. Neuromuscul Disord 8:480-488

Gualano B, Novaes RB, Artioli GG, Freire TO, Coelho DF, Scagliusi FB, Rogeri PS, Roschel H, Ugrinowitsch C, Lancha AH Jr (2008a) Effects of creatine supplementation on glucose tolerance and insulin sensitivity in sedentary healthy males undergoing aerobic training. Amino Acids 34:245-250

Gualano B, Ugrinowitsch C, Novaes RB, Artioli GG, Shimizu MH, Seguro AC, Harris RC, Lancha AH Jr (2008b) Effects of creatine supplementation on renal function: a randomized, double-blind, placebo-controlled clinical trial. Eur J Appl Physiol 103:33-40

Gualano B, Ferreira DC, Sapienza MT, Seguro AC, Lancha AH Jr (2010) Effect of short-term high-dose creatine supplementation on measured GFR in a young man with a single kidney. Am J Kidney Dis 55:e7-e9

Guerrero ML, Beron J, Spindler B, Groscurth P, Wallimann T, Verrey F (1997) Metabolic support of Na+ pump in apically permeabilized A6 kidney cell epithelia: role of creatine kinase. Am J Physiol 272:C697-C706

Guidi C, Potenza L, Sestili P, Martinelli C, Guescini M, Stocchi L, Zeppa S, Polidori E, Annibalini G, Stocchi V (2008) Differential effect of creatine on oxidatively-injured mitochondrial and nuclear DNA. Biochim Biophys Acta 1780:16-26

Hadjicharalambous M, Kilduff LP, Pitsiladis YP (2008) Brain serotonin and dopamine modulators, perceptual responses and endurance performance during exercise in the heat following creatine supplementation. J Int Soc Sports Nutr 5:14

Harris RC, Soderlund K, Hultman E (1992) Elevation of creatine in resting and exercised muscle of normal subjects by creatine supplementation. Clin Sci (Lond) 83:367-374

Harris RC, Lowe JA, Warnes K, Orme CE (1997) The concentration of creatine in meat, offal and commercial dog food. Res Vet Sci 62:58-62

Hatano E, Tanaka A, Iwata S, Satoh S, Kitai T, Tsunekawa S, Inomoto T, Shinohara H, Chance B, Yamaoka Y (1996) Induction of endotoxin tolerance in transgenic mouse liver expressing creatine kinase. Hepatology 24:663-669

Hatano E, Tanaka A, Kanazawa A, Tsuyuki S, Tsunekawa S, Iwata S, Takahashi R, Chance B, Yamaoka Y (2004) Inhibition of tumor necrosis factor-induced apoptosis in transgenic mouse liver expressing creatine kinase. Liver Int 24:384-393

Hausmann ON, Fouad K, Wallimann T, Schwab ME (2002) Protective effects of oral creatine supplementation on spinal cord injury in rats. Spinal Cord 40:449-456

Hemmer W, Riesinger I, Wallimann T, Eppenberger HM, Quest AF (1993) Brain-type creatine kinase in photoreceptor cell outer segments: role of a phosphocreatine circuit in outer segment energy metabolism and phototransduction. J Cell Sci 106(Pt 2):671-683

Hespel P, Derave W (2007) Ergogenic effects of creatine in sports and rehabilitation. Subcell Biochem 46:245-259
Hespel P, Op't Eijnde B, Van Leemputte M, Urso B, Greenhaff PL, Labarque V, Dymarkowski S, Van Hecke P, Richter EA (2001) Oral creatine supplementation facilitates the rehabilitation of disuse atrophy and alters the expression of muscle myogenic factors in humans. J Physiol 536:625-633

Hornemann T, Stolz M, Wallimann T (2000) Isoenzyme-specific interaction of muscle-type creatine kinase with the sarcomeric M-line is mediated by $\mathrm{NH}(2)$-terminal lysine charge-clamps. J Cell Biol 149:1225-1234

Hornemann T, Kempa S, Himmel M, Hayess K, Furst DO, Wallimann T (2003) Muscle-type creatine kinase interacts with central domains of the M-band proteins myomesin and M-protein. J Mol Biol 332:877-887

Hosamani R, Ramesh SR, Muralidhara (2010) Attenuation of rotenone-induced mitochondrial oxidative damage and neurotoxicty in Drosophila melanogaster supplemented with creatine. Neurochem Res 35:1402-1412

Hu F, Furihata K, Ito-Ishida M, Kaminogawa S, Tanokura M (2004) Nondestructive observation of bovine milk by NMR spectroscopy: analysis of existing States of compounds and detection of new compounds. J Agric Food Chem 52:4969-4974

Hulsemann J, Manz F, Wember T, Schoch G (1987) Administration of creatine and creatinine with breast milk and infant milk preparations. Klin Padiatr 199:292-295

Hurtley S (2009) Spatial cell biology. Location, location, location. Introduction. Science 326:1205

In 't Zandt HJ, Renema WK, Streijger F, Jost C, Klomp DW, Oerlemans F, Van der Zee CE, Wieringa B, Heerschap A (2004) Cerebral creatine kinase deficiency influences metabolite levels and morphology in the mouse brain: a quantitative in vivo $1 \mathrm{H}$ and 31P magnetic resonance study. J Neurochem 90:1321-1330

Ireland Z, Dickinson H, Snow R, Walker DW (2008) Maternal creatine: does it reach the fetus and improve survival after an acute hypoxic episode in the spiny mouse (Acomys cahirinus)? Am J Obstet Gynecol 198(431):e431-e436

Ireland Z, Russell AP, Wallimann T, Walker DW, Snow R (2009) Developmental changes in the expression of creatine synthesizing enzymes and creatine transporter in a precocial rodent, the spiny mouse. BMC Dev Biol 9:39

Johnston AP, Burke DG, MacNeil LG, Candow DG (2009) Effect of creatine supplementation during cast-induced immobilization on the preservation of muscle mass, strength, and endurance. J Strength Cond Res 23:116-120

Jost CR, Van Der Zee CE, In 't Zandt HJ, Oerlemans F, Verheij M, Streijger F, Fransen J, Heerschap A, Cools AR, Wieringa B (2002) Creatine kinase B-driven energy transfer in the brain is important for habituation and spatial learning behaviour, mossy fibre field size and determination of seizure susceptibility. Eur J Neurosci 15:1692-1706

Kaasik A, Veksler V, Boehm E, Novotova M, Ventura-Clapier R (2003) From energy store to energy flux: a study in creatine kinase-deficient fast skeletal muscle. FASEB J 17:708-710

Kaldis P, Hemmer W, Zanolla E, Holtzman D, Wallimann T (1996a) 'Hot spots' of creatine kinase localization in brain: cerebellum, hippocampus and choroid plexus. Dev Neurosci 18:542-554

Kaldis P, Stolz M, Wyss M, Zanolla E, Rothen-Rutishauser B, Vorherr T, Wallimann T (1996b) Identification of two distinctly localized mitochondrial creatine kinase isoenzymes in spermatozoa. J Cell Sci 109(Pt 8):2079-2088

Kaldis P, Kamp G, Piendl T, Wallimann T (1997) Functions of creatine kinase isoenzymes in spermatozoa. Adv Dev Biochem 5:275-312

Kamber M, Koster M, Kreis R, Walker G, Boesch C, Hoppeler H (1999) Creatine supplementation-part I: performance, clinical chemistry, and muscle volume. Med Sci Sports Exerc $31: 1763-1769$ 
Kay L, Nicolay K, Wieringa B, Saks V, Wallimann T (2000) Direct evidence for the control of mitochondrial respiration by mitochondrial creatine kinase in oxidative muscle cells in situ. J Biol Chem 275:6937-6944

Kennaugh L, Arthur P, Hartmann E (1997) The concentration of creatine and creatine phosphate in sow colostrum and milk throughout lactation and weaning. Aust J Agric Res 48:1105-1111

Kerksick C, Harvey T, Stout J, Campbell B, Wilborn C, Kreider R, Kalman D, Ziegenfuss T, Lopez H, Landis J, Ivy JL, Antonio J (2008) International Society of Sports Nutrition position stand: nutrient timing. J Int Soc Sports Nutr 5:17 (Erratum in J Int Soc Sports Nutr 5:18)

Klivenyi P, Ferrante RJ, Matthews RT, Bogdanov MB, Klein AM, Andreassen OA, Mueller G, Wermer M, Kaddurah-Daouk R, Beal MF (1999) Neuroprotective effects of creatine in a transgenic animal model of amyotrophic lateral sclerosis. Nat Med 5:347-350

Kottke M, Adams V, Wallimann T, Nalam VK, Brdiczka D (1991) Location and regulation of octameric mitochondrial creatine kinase in the contact sites. Biochim Biophys Acta 1061:215-225

Kraemer WJ, Volek JS (1999) Creatine supplementation. Its role in human performance. Clin Sports Med 18:651-666 ix

Kraft T, Hornemann T, Stolz M, Nier V, Wallimann T (2000) Coupling of creatine kinase to glycolytic enzymes at the sarcomeric I-band of skeletal muscle: a biochemical study in situ. J Muscle Res Cell Motil 21:691-703

Kreider RB, Melton C, Rasmussen CJ, Greenwood M, Lancaster S, Cantler EC, Milnor P, Almada AL (2003) Long-term creatine supplementation does not significantly affect clinical markers of health in athletes. Mol Cell Biochem 244:95-104

Kroemer G, Galluzzi L, Brenner C (2007) Mitochondrial membrane permeabilization in cell death. Physiol Rev 87:99-163

Kuiper JW, Pluk H, Oerlemans F, van Leeuwen FN, de Lange F, Fransen J, Wieringa B (2008) Creatine kinase-mediated ATP supply fuels actin-based events in phagocytosis. PLoS Biol 6:e51

Kuiper JW, van Horssen R, Oerlemans F, Peters W, van Dommelen MM, te Lindert MM, ten Hagen TL, Janssen E, Fransen JA, Wieringa B (2009) Local ATP generation by brain-type creatine kinase (CK-B) facilitates cell motility. PLoS One 4:e5030

Kumar D, Russell JJ, Barnes AC (1962) Studies in human myometrium during pregnancy. III. Distribution of high phosphate compounds (adenosinetriphosphate and phosphocreatine). Am J Obstet Gynecol 84:586-590

Lamarre SG, Edison EE, Wijekoon EP, Brosnan ME, Brosnan JT (2010) Suckling rat pups accumulate creatine primarily via de novo synthesis rather than from dam milk. J Nutr 140:1570-1573

Lawler JM, Barnes WS, Wu G, Song W, Demaree S (2002) Direct antioxidant properties of creatine. Biochem Biophys Res Commun 290:47-52

Lenz H, Schmidt M, Welge V, Schlattner U, Wallimann T, Elsasser HP, Wittern KP, Wenck H, Stab F, Blatt T (2005) The creatine kinase system in human skin: protective effects of creatine against oxidative and UV damage in vitro and in vivo. J Invest Dermatol 124:443-452

Li H, Thali RF, Smolak C, Gong F, Alzamora R, Wallimann T, Scholz R, Pastor-Soler NM, Neumann D, Hallows KR (2010) Regulation of the creatine transporter by AMP-activated protein kinase in kidney epithelial cells. Am J Physiol Renal Physiol 299:F167-F177

Linton JD, Holzhausen LC, Babai N, Song H, Miyagishima KJ, Stearns GW, Lindsay K, Wei J, Chertov AO, Peters TA, Caffe R, Pluk H, Seeliger MW, Tanimoto N, Fong K, Bolton L, Kuok DL, Sweet IR, Bartoletti TM, Radu RA, Travis GH, Zagotta WN, Townes-Anderson E, Parker E, Van der Zee CE, Sampath AP,
Sokolov M, Thoreson WB, Hurley JB (2010) Flow of energy in the outer retina in darkness and in light. Proc Natl Acad Sci USA 107:8599-8604

Louis M, Van Beneden R, Dehoux M, Thissen JP, Francaux M (2004) Creatine increases IGF-I and myogenic regulatory factor mRNA in $\mathrm{C}(2) \mathrm{C}(12)$ cells. FEBS Lett 557:243-247

Maniti O, Lecompte MF, Marcillat O, Vial C, Granjon T (2010) Mitochondrial creatine kinase interaction with cardiolipin-containing biomimetic membranes is a two-step process involving adsorption and insertion. Eur Biophys J 39:1649-1655

Matthews RT, Yang L, Jenkins BG, Ferrante RJ, Rosen BR, Kaddurah-Daouk R, Beal MF (1998) Neuroprotective effects of creatine and cyclocreatine in animal models of Huntington's disease. J Neurosci 18:156-163

McLeish MJ, Kenyon GL (2005) Relating structure to mechanism in creatine kinase. Crit Rev Biochem Mol Biol 40:1-20

McMorris T, Mielcarz G, Harris RC, Swain JP, Howard A (2007) Creatine supplementation and cognitive performance in elderly individuals. Neuropsychol Dev Cogn B Aging Neuropsychol Cogn 14:517-528

McPherron SP, Alemseged Z, Marean CW, Wynn JG, Reed D, Geraads D, Bobe R, Bearat HA (2010) Evidence for stone-toolassisted consumption of animal tissues before 3.39 million years ago at Dikika, Ethiopia. Nature 466:857-860

Mekhfi H, Hoerter J, Lauer C, Wisnewsky C, Schwartz K, VenturaClapier R (1990) Myocardial adaptation to creatine deficiency in rats fed with beta-guanidinopropionic acid, a creatine analogue. Am J Physiol 258:H1151-H1158

Mellanby E (1913) The metabolism of lactating women. Proc Royal Soc Series B 86:88-109

Meyer LE, Machado LB, Santiago AP, da-Silva WS, De Felice FG, Holub O, Oliveira MF, Galina A (2006) Mitochondrial creatine kinase activity prevents reactive oxygen species generation: antioxidant role of mitochondrial kinases-dependent ADP recycling activity. J Biol Chem 281:37361-37371

Miller K, Halow J, Koretsky AP (1993) Phosphocreatine protects transgenic mouse liver expressing creatine kinase from hypoxia and ischemia. Am J Physiol 265:C1544-C1551

Milton K (2003) The critical role played by animal source foods in human (Homo) evolution. J Nutr 133:3886S-3892S

Minami SB, Yamashita D, Ogawa K, Schacht J, Miller JM (2007) Creatine and tempol attenuate noise-induced hearing loss. Brain Res 1148:83-89

Morley JE, Argiles JM, Evans WJ, Bhasin S, Cella D, Deutz NE, Doehner W, Fearon KC, Ferrucci L, Hellerstein MK, KalantarZadeh K, Lochs H, MacDonald N, Mulligan K, Muscaritoli M, Ponikowski P, Posthauer ME, Rossi Fanelli F, Schambelan M, Schols AM, Schuster MW, Anker SD (2010) Nutritional recommendations for the management of sarcopenia. J Am Med Dir Assoc 11:391-396

Mudd SH, Brosnan JT, Brosnan ME, Jacobs RL, Stabler SP, Allen RH, Vance DE, Wagner C (2007) Methyl balance and transmethylation fluxes in humans. Am J Clin Nutr 85:19-25

Newmeyer A, Cecil KM, Schapiro M, Clark JF, Degrauw TJ (2005) Incidence of brain creatine transporter deficiency in males with developmental delay referred for brain magnetic resonance imaging. J Dev Behav Pediatr 26:276-282

Novotova M, Pavlovicova M, Veksler VI, Ventura-Clapier R, Zahradnik I (2006) Ultrastructural remodeling of fast skeletal muscle fibers induced by invalidation of creatine kinase. Am J Physiol Cell Physiol 291:C1279-C1285

O'Gorman E, Beutner G, Wallimann T, Brdiczka D (1996) Differential effects of creatine depletion on the regulation of enzyme activities and on creatine-stimulated mitochondrial respiration in skeletal muscle, heart, and brain. Biochim Biophys Acta 1276:161-170 
O'Gorman E, Beutner G, Dolder M, Koretsky AP, Brdiczka D, Wallimann T (1997a) The role of creatine kinase in inhibition of mitochondrial permeability transition. FEBS Lett 414:253-257

O'Gorman E, Piendl T, Muller M, Brdiczka D, Wallimann T (1997b) Mitochondrial intermembrane inclusion bodies: the common denominator between human mitochondrial myopathies and creatine depletion, due to impairment of cellular energetics. Mol Cell Biochem 174:283-289

Ogimoto G, Sakurada T, Imamura K, Kuboshima S, Maeba T, Kimura K, Owada S (2003) Alteration of energy production by the heart in CRF patients undergoing peritoneal dialysis. Mol Cell Biochem 244:135-138

Pastoris O, Aquilani R, Foppa P, Bovio G, Segagni S, Baiardi P, Catapano M, Maccario M, Salvadeo A, Dossena M (1997) Altered muscle energy metabolism in post-absorptive patients with chronic renal failure. Scand J Urol Nephrol 31:281-287

Peral MJ, Galvez M, Soria ML, Ilundain AA (2005) Developmental decrease in rat small intestinal creatine uptake. Mech Ageing Dev 126:523-530

Persky AM, Rawson ES (2007) Safety of creatine supplementation. Subcell Biochem 46:275-289

Pischel I, Gastner T (2007) Creatine-its chemical synthesis, chemistry, and legal status. Subcell Biochem 46:291-307

Prass K, Royl G, Lindauer U, Freyer D, Megow D, Dirnagl U, Stockler-Ipsiroglu G, Wallimann T, Priller J (2007) Improved reperfusion and neuroprotection by creatine in a mouse model of stroke. J Cereb Blood Flow Metab 27:452-459

Pulido SM, Passaquin AC, Leijendekker WJ, Challet C, Wallimann T, Ruegg UT (1998) Creatine supplementation improves intracellular $\mathrm{Ca} 2+$ handling and survival in mdx skeletal muscle cells. FEBS Lett 439:357-362

Quest AF, Harvey DJ, McIlhinney RA (1997) Myristoylated and nonmyristoylated pools of sea urchin sperm flagellar creatine kinase exist side-by-side: myristoylation is necessary for efficient lipid association. Biochemistry 36:6993-7002

Quistorff B, Johansen L, Sahlin K (1993) Absence of phosphocreatine resynthesis in human calf muscle during ischaemic recovery. Biochem J 291(Pt 3):681-686

Rae C, Digney AL, McEwan SR, Bates TC (2003) Oral creatine monohydrate supplementation improves brain performance: a double-blind, placebo-controlled, cross-over trial. Proc Biol Sci 270:2147-2150

Rao JK, Bujacz G, Wlodawer A (1998) Crystal structure of rabbit muscle creatine kinase. FEBS Lett 439:133-137

Rawson ES, Stec MJ, Frederickson SJ, Miles MP (2011) Low-dose creatine supplementation enhances fatigue resistance in the absence of weight gain. Nutrition 27:451-455

Richards MP (2002) A brief review of the archaeological evidence for Palaeolithic and Neolithic subsistence. Eur J Clin Nutr 56:16 p following 1262

Rodriguez MC, MacDonald JR, Mahoney DJ, Parise G, Beal MF, Tarnopolsky MA (2007) Beneficial effects of creatine, CoQ10, and lipoic acid in mitochondrial disorders. Muscle Nerve 35:235-242

Rojo M, Hovius R, Demel RA, Nicolay K, Wallimann T (1991) Mitochondrial creatine kinase mediates contact formation between mitochondrial membranes. J Biol Chem 266:20290-20295

Rossi AM, Eppenberger HM, Volpe P, Cotrufo R, Wallimann T (1990) Muscle-type MM creatine kinase is specifically bound to sarcoplasmic reticulum and can support $\mathrm{Ca} 2+$ uptake and regulate local ATP/ADP ratios. J Biol Chem 265:5258-5266

Rostovtseva TK, Sheldon KL, Hassanzadeh E, Monge C, Saks V, Bezrukov SM, Sackett DL (2008) Tubulin binding blocks mitochondrial voltage-dependent anion channel and regulates respiration. Proc Natl Acad Sci USA 105:18746-18751
Safdar A, Yardley NJ, Snow R, Melov S, Tarnopolsky MA (2008) Global and targeted gene expression and protein content in skeletal muscle of young men following short-term creatine monohydrate supplementation. Physiol Genomics 32:219-228

Sakellaris G, Kotsiou M, Tamiolaki M, Kalostos G, Tsapaki E, Spanaki M, Spilioti M, Charissis G, Evangeliou A (2006) Prevention of complications related to traumatic brain injury in children and adolescents with creatine administration: an open label randomized pilot study. J Trauma 61:322-329

Saks VA (ed) (2007) Molecular systems bioenergetics: energy for life. Wiley, Weinheim

Saks VA, Rosenshtraukh LV, Smirnov VN, Chazov EI (1978) Role of creatine phosphokinase in cellular function and metabolism. Can J Physiol Pharmacol 56:691-706

Saks VA, Ventura-Clapier R, Huchua ZA, Preobrazhensky AN, Emelin IV (1984) Creatine kinase in regulation of heart function and metabolism. I. Further evidence for compartmentation of adenine nucleotides in cardiac myofibrillar and sarcolemmal coupled ATPase-creatine kinase systems. Biochim Biophys Acta 803:254-264

Saks V, Stepanov V, Jaliashvili IV, Konorev EA, Kryzkanovsky SA, Strumia E (1996) Molecular and cellular mechanisms of action for the cardioprotective and therapeutic role of creatine phosphate. In: Conway MA, Clark JF (eds) Creatine and creatine phosphate: scientific and clinical perspectives. Academic Press, San Diego, pp 91-114

Saks VA, Kongas O, Vendelin M, Kay L (2000) Role of the creatine/ phosphocreatine system in the regulation of mitochondrial respiration. Acta Physiol Scand 168:635-641

Saks V, Dzeja P, Schlattner U, Vendelin M, Terzic A, Wallimann T (2006a) Cardiac system bioenergetics: metabolic basis of the Frank-Starling law. J Physiol 571:253-273

Saks V, Favier R, Guzun R, Schlattner U, Wallimann T (2006b) Molecular system bioenergetics: regulation of substrate supply in response to heart energy demands. J Physiol 577:769-777

Santos RV, Bassit RA, Caperuto EC, Costa Rosa LF (2004) The effect of creatine supplementation upon inflammatory and muscle soreness markers after a $30 \mathrm{~km}$ race. Life Sci 75:1917-1924

Santos RV, Batista ML Jr, Caperuto EC, Costa Rosa LF (2007) Chronic supplementation of creatine and vitamins $\mathrm{C}$ and $\mathrm{E}$ increases survival and improves biochemical parameters after Doxorubicin treatment in rats. Clin Exp Pharmacol Physiol 34:1294-1299

Schedel JM, Tanaka H, Kiyonaga A, Shindo M, Schutz Y (1999) Acute creatine ingestion in human: consequences on serum creatine and creatinine concentrations. Life Sci 65:2463-2470

Schlattner U, Wallimann $\mathrm{T}$ (2000) Octamers of mitochondrial creatine kinase isoenzymes differ in stability and membrane binding. J Biol Chem 275:17314-17320

Schlattner U, Eder M, Dolder M, Khuchua ZA, Strauss AW, Wallimann T (2000) Divergent enzyme kinetics and structural properties of the two human mitochondrial creatine kinase isoenzymes. Biol Chem 381:1063-1070

Schlattner U, Dolder M, Wallimann T, Tokarska-Schlattner M (2001) Mitochondrial creatine kinase and mitochondrial outer membrane porin show a direct interaction that is modulated by calcium. J Biol Chem 276:48027-48030

Schlattner U, Mockli N, Speer O, Werner S, Wallimann T (2002) Creatine kinase and creatine transporter in normal, wounded, and diseased skin. J Invest Dermatol 118:416-423

Schlattner U, Gehring F, Vernoux N, Tokarska-Schlattner M, Neumann D, Marcillat O, Vial C, Wallimann T (2004) C-terminal lysines determine phospholipid interaction of sarcomeric mitochondrial creatine kinase. J Biol Chem 279:2433424342 
Schlattner U, Tokarska-Schlattner M, Wallimann T (2006a) Mitochondrial creatine kinase in human health and disease. Biochim Biophys Acta 1762:164-180

Schlattner U, Tokarska-Schlattner M, Wallimann T (2006b) Molecular structure and function of mitochondrial creatine kinases. In: Vial C (ed), Uversky VN (series ed) Creatine kinase-biochemistry, physiology, structure and function. Nova Science Publishers, New York, pp 123-170

Schlattner U, Tokarska-Schlatner M, Wallimann T (2011) Metabolite channeling: creatine kinase microcompartments. In: Lennarz WJ and Lane DW (eds) Encyclopedia of biological chemistry. Elsevier (in press)

Schnyder T, Cyrklaff M, Fuchs K, Wallimann T (1994) Crystallization of mitochondrial creatine kinase on negatively charged lipid layers. J Struct Biol 112:136-147

Schulze A (2003) Creatine deficiency syndromes. Mol Cell Biochem 244:143-150

Scopes RK (1973) Studies with a reconstituted muscle glycolytic system. The rate and extent of creatine phosphorylation by anaerobic glycolysis. Biochem J 134:197-208

Sestili P, Martinelli C, Bravi G, Piccoli G, Curci R, Battistelli M, Falcieri E, Agostini D, Gioacchini AM, Stocchi V (2006) Creatine supplementation affords cytoprotection in oxidatively injured cultured mammalian cells via direct antioxidant activity. Free Radic Biol Med 40:837-849

Sheffy BE, Shahani KM, Grummer RH, Phillips PH, Sommer HH (1952) Nitrogen constituents of sow's milk as affected by ration and stage of lactation. J Nutr 48:103-114

Shin JB, Streijger F, Beynon A, Peters T, Gadzala L, McMillen D, Bystrom C, Van der Zee CE, Wallimann T, Gillespie PG (2007) Hair bundles are specialized for ATP delivery via creatine kinase. Neuron 53:371-386

Shulman RG (2005) Glycogen turnover forms lactate during exercise. Exerc Sport Sci Rev 33:157-162

Sipila I (1980) Inhibition of arginine-glycine amidinotransferase by ornithine. A possible mechanism for the muscular and chorioretinal atrophies in gyrate atrophy of the choroid and retina with hyperornithinemia. Biochim Biophys Acta 613:79-84

Sistermans EA, de Kok YJ, Peters W, Ginsel LA, Jap PH, Wieringa B (1995a) Tissue- and cell-specific distribution of creatine kinase B: a new and highly specific monoclonal antibody for use in immunohistochemistry. Cell Tissue Res 280:435-446

Sistermans EA, Klaassen CH, Peters W, Swarts HG, Jap PH, De Pont JJ, Wieringa B (1995b) Co-localization and functional coupling of creatine kinase B and gastric $\mathrm{H}+/ \mathrm{K}(+)$-ATPase on the apical membrane and the tubulovesicular system of parietal cells. Biochem J 311(Pt 2):445-451

Speer O, Neukomm LJ, Murphy RM, Zanolla E, Schlattner U, Henry H, Snow RJ, Wallimann T (2004) Creatine transporters: a reappraisal. Mol Cell Biochem 256-257:407-424

Speer O, Back N, Buerklen T, Brdiczka D, Koretsky A, Wallimann T, Eriksson O (2005) Octameric mitochondrial creatine kinase induces and stabilizes contact sites between the inner and outer membrane. Biochem J 385:445-450

Spicer SS, Schulte BA (1992) Creatine kinase in epithelium of the inner ear. J Histochem Cytochem 40:185-192

Stachowiak O, Dolder M, Wallimann T (1996) Membrane-binding and lipid vesicle cross-linking kinetics of the mitochondrial creatine kinase octamer. Biochemistry 35:15522-15528

Stachowiak O, Schlattner U, Dolder M, Wallimann T (1998) Oligomeric state and membrane binding behaviour of creatine kinase isoenzymes: implications for cellular function and mitochondrial structure. Mol Cell Biochem 184:141-151

Stadhouders AM, Jap PH, Winkler HP, Eppenberger HM, Wallimann T (1994) Mitochondrial creatine kinase: a major constituent of pathological inclusions seen in mitochondrial myopathies. Proc Natl Acad Sci USA 91:5089-5093

Steeghs K, Benders A, Oerlemans F, de Haan A, Heerschap A, Ruitenbeek W, Jost C, van Deursen J, Perryman B, Pette D, Bruckwilder M, Koudijs J, Jap P, Veerkamp J, Wieringa B (1997) Altered $\mathrm{Ca} 2+$ responses in muscles with combined mitochondrial and cytosolic creatine kinase deficiencies. Cell 89:93-103

Steeghs K, Oerlemans F, de Haan A, Heerschap A, Verdoodt L, de Bie M, Ruitenbeek W, Benders A, Jost C, van Deursen J, Tullson P, Terjung R, Jap P, Jacob W, Pette D, Wieringa B (1998) Cytoarchitectural and metabolic adaptations in muscles with mitochondrial and cytosolic creatine kinase deficiencies. Mol Cell Biochem 184:183-194

Straumann N, Wind A, Leuenberger T, Wallimann T (2006) Effects of N-linked glycosylation on the creatine transporter. Biochem J 393:459-469

Streijger F, Oerlemans F, Ellenbroek BA, Jost CR, Wieringa B, Van der Zee CE (2005) Structural and behavioural consequences of double deficiency for creatine kinases BCK and UbCKmit. Behav Brain Res 157:219-234

Streijger F, Pluk H, Oerlemans F, Beckers G, Bianco AC, Ribeiro MO, Wieringa B, Van der Zee CE (2009) Mice lacking braintype creatine kinase activity show defective thermoregulation. Physiol Behav 97:76-86

Streijger F, Scheenen WJ, van Luijtelaar G, Oerlemans F, Wieringa B, Van der Zee CE (2010) Complete brain-type creatine kinase deficiency in mice blocks seizure activity and affects intracellular calcium kinetics. Epilepsia 51:79-88

Sullivan PG, Geiger JD, Mattson MP, Scheff SW (2000) Dietary supplement creatine protects against traumatic brain injury. Ann Neurol 48:723-729

Tachikawa M, Hosoya K, Ohtsuki S, Terasaki T (2007) A novel relationship between creatine transport at the blood-brain and blood-retinal barriers, creatine biosynthesis, and its use for brain and retinal energy homeostasis. Subcell Biochem 46:83-98

Tagami T, Sakuma H, Matsumura K, Takeda K, Mori S, Takeuchi T, Nakano T (1998) Evaluation of altered myocardial high energy phosphate metabolism in patients on maintenance dialysis using phosphorus-31 magnetic resonance spectroscopy. Invest Radiol 33:171-176

Tarnopolsky MA (2007) Clinical use of creatine in neuromuscular and neurometabolic disorders. Subcell Biochem 46:183-204

Tarnopolsky MA, Simon DK, Roy BD, Chorneyko K, Lowther SA, Johns DR, Sandhu JK, Li Y, Sikorska M (2004) Attenuation of free radical production and paracrystalline inclusions by creatine supplementation in a patient with a novel cytochrome $b$ mutation. Muscle Nerve 29:537-547

Tokarska-Schlattner M, Wallimann T, Schlattner U (2002) Multiple interference of anthracyclines with mitochondrial creatine kinases: preferential damage of the cardiac isoenzyme and its implications for drug cardiotoxicity. Mol Pharmacol 61:516-523

Tokarska-Schlattner M, Meiler F, Zandomeneghi G, Meier BH, Saks V, Neumann D, Wallimann T, Schlattner U (2003) Do creatine and other guanidino compounds bind to phospholipid membranes? Studies with SPR and P-31-NMR-spectroscopy. Biophys J 84:49A

Tokarska-Schlattner M, Wallimann T, Schlattner U (2005a) Membrane protective effects of phosphocreatine. Biophys J 88:418A

Tokarska-Schlattner M, Zaugg M, da Silva R, Lucchinetti E, Schaub MC, Wallimann T, Schlattner U (2005b) Acute toxicity of doxorubicin on isolated perfused heart: response of kinases regulating energy supply. Am J Physiol Heart Circ Physiol 289:H37-H47

Tokarska-Schlattner M, Zaugg M, Zuppinger C, Wallimann T, Schlattner U (2006) New insights into doxorubicin-induced 
cardiotoxicity: the critical role of cellular energetics. J Mol Cell Cardiol 41:389-405

Tokarska-Schlattner M, Dolder M, Gerber I, Speer O, Wallimann T, Schlattner U (2007) Reduced creatine-stimulated respiration in doxorubicin challenged mitochondria: particular sensitivity of the heart. Biochim Biophys Acta 1767:1276-1284

Tombes RM, Shapiro BM (1987) Enzyme termini of a phosphocreatine shuttle. Purification and characterization of two creatine kinase isozymes from sea urchin sperm. J Biol Chem 262:16011-16019

Tombes RM, Brokaw CJ, Shapiro BM (1987) Creatine kinasedependent energy transport in sea urchin spermatozoa. Flagellar wave attenuation and theoretical analysis of high energy phosphate diffusion. Biophys J 52:75-86

Ulijaszek SJ (2002) Comparative energetics of primate fetal growth. Am J Hum Biol 14:603-608

Valastro B, Dekundy A, Danysz W, Quack G (2009) Oral creatine supplementation attenuates L-DOPA-induced dyskinesia in 6-hydroxydopamine-lesioned rats. Behav Brain Res 197:90-96

van den Thillart G, van Waarde A, Muller HJ, Erkelens C, Addink A, Lugtenburg J (1989) Fish muscle energy metabolism measured by in vivo 31P-NMR during anoxia and recovery. Am J Physiol 256:R922-R929

van Deursen J, Heerschap A, Oerlemans F, Ruitenbeek W, Jap P, ter Laak H, Wieringa B (1993) Skeletal muscles of mice deficient in muscle creatine kinase lack burst activity. Cell 74:621-631

van Deursen J, Ruitenbeek W, Heerschap A, Jap P, ter Laak H, Wieringa B (1994) Creatine kinase (CK) in skeletal muscle energy metabolism: a study of mouse mutants with graded reduction in muscle CK expression. Proc Natl Acad Sci USA 91:9091-9095

van Dorsten FA, Furter R, Bijkerk M, Wallimann T, Nicolay K (1996) The in vitro kinetics of mitochondrial and cytosolic creatine kinase determined by saturation transfer 31P-NMR. Biochim Biophys Acta 1274:59-66

van Dorsten FA, Wyss M, Wallimann T, Nicolay K (1997) Activation of sea-urchin sperm motility is accompanied by an increase in the creatine kinase exchange flux. Biochem J 325(Pt 2):411-416

van Leemputte M, Vandenberghe K, Hespel P (1999) Shortening of muscle relaxation time after creatine loading. J Appl Physiol 86:840-844

Van Waarde A, Van den Thillart G, Erkelens C, Addink A, Lugtenburg J (1990) Functional coupling of glycolysis and phosphocreatine utilization in anoxic fish muscle. An in vivo 31P NMR study. J Biol Chem 265:914-923

Veksler VI, Kuznetsov AV, Anflous K, Mateo P, van Deursen J, Wieringa B, Ventura-Clapier R (1995) Muscle creatine kinasedeficient mice. II. Cardiac and skeletal muscles exhibit tissuespecific adaptation of the mitochondrial function. J Biol Chem 270:19921-19929

Vendelin M, Lemba M, Saks VA (2004) Analysis of functional coupling: mitochondrial creatine kinase and adenine nucleotide translocase. Biophys J 87:696-713

Ventura-Clapier R, Mekhfi H, Vassort G (1987) Role of creatine kinase in force development in chemically skinned rat cardiac muscle. J Gen Physiol 89:815-837

Ventura-Clapier R, Kuznetsov AV, d'Albis A, van Deursen J, Wieringa B, Veksler VI (1995) Muscle creatine kinase-deficient mice. I. Alterations in myofibrillar function. J Biol Chem 270:19914-19920

Ventura-Clapier R, Kaasik A, Veksler V (2004) Structural and functional adaptations of striated muscles to CK deficiency. Mol Cell Biochem 256-257:29-41

Wallimann T (1975) Creatine kinase isoenzymes and myofibrillar structure. PhD Thesis Nr 5437, ETH Zurich

Wallimann T, Eppenberger HM (1973) Properties of arginine kinase from Drosophila melanogaster. Eur J Biochem 38:180-184
Wallimann T, Eppenberger HM (1985) Localization and function of M-line-bound creatine kinase. M-band model and creatine phosphate shuttle. Cell Muscle Motil 6:239-285

Wallimann T, Hemmer W (1994) Creatine kinase in non-muscle tissues and cells. Mol Cell Biochem 133-134:193-220

Wallimann T, Schlosser T, Eppenberger HM (1984) Function of M-line-bound creatine kinase as intramyofibrillar ATP regenerator at the receiving end of the phosphorylcreatine shuttle in muscle. J Biol Chem 259:5238-5246

Wallimann T, Moser H, Zurbriggen B, Wegmann G, Eppenberger HM (1986a) Creatine kinase isoenzymes in spermatozoa. J Muscle Res Cell Motil 7:25-34

Wallimann T, Wegmann G, Moser H, Huber R, Eppenberger HM (1986b) High content of creatine kinase in chicken retina: compartmentalized localization of creatine kinase isoenzymes in photoreceptor cells. Proc Natl Acad Sci USA 83:3816-3819

Wallimann T, Wyss M, Brdiczka D, Nicolay K, Eppenberger HM (1992) Intracellular compartmentation, structure and function of creatine kinase isoenzymes in tissues with high and fluctuating energy demands: the 'phosphocreatine circuit' for cellular energy homeostasis. Biochem J 281(Pt 1):21-40

Wallimann T, Dolder M, Schlattner U, Eder M, Hornemann T, O'Gorman E, Ruck A, Brdiczka D (1998) Some new aspects of creatine kinase $(\mathrm{CK})$ : compartmentation, structure, function and regulation for cellular and mitochondrial bioenergetics and physiology. Biofactors 8:229-234

Wallimann T, Tokarska-Schlattner M, Neumann D, Epand RM, Epand RF, Andres RH, Widmer HR, Hornemann T, Saks V, Agarkova I, Schlattner U (2007) The phospho-creatine circuit: molecular and cellular physiology of creatine kinases, sensitivity to free radicals and enhancement by creatine supplementation. In: Saks VA (ed) Molecular systems bioenergetics: energy for life. Wiley, Weinheim, pp 195-264

Watanabe A, Kato N, Kato T (2002) Effects of creatine on mental fatigue and cerebral hemoglobin oxygenation. Neurosci Res 42:279-285

Watchko JF, Daood MJ, Wieringa B, Koretsky AP (2000) Myofibrillar or mitochondrial creatine kinase deficiency alone does not impair mouse diaphragm isotonic function. J Appl Physiol 88:973-980

Watt KK, Garnham AP, Snow RJ (2004) Skeletal muscle total creatine content and creatine transporter gene expression in vegetarians prior to and following creatine supplementation. Int $\mathrm{J}$ Sport Nutr Exerc Metab 14:517-531

Wegmann G, Huber R, Zanolla E, Eppenberger HM, Wallimann T (1991) Differential expression and localization of brain-type and mitochondrial creatine kinase isoenzymes during development of the chicken retina: Mi-CK as a marker for differentiation of photoreceptor cells. Differentiation 46:77-87

Wegmann G, Zanolla E, Eppenberger HM, Wallimann T (1992) In situ compartmentation of creatine kinase in intact sarcomeric muscle: the acto-myosin overlap zone as a molecular sieve. J Muscle Res Cell Motil 13:420-435

Wyss M, Kaddurah-Daouk R (2000) Creatine and creatinine metabolism. Physiol Rev 80:1107-1213

Wyss M, Schulze A (2002) Health implications of creatine: can oral creatine supplementation protect against neurological and atherosclerotic disease? Neuroscience 112:243-260

Wyss M, Wallimann T (1994) Creatine metabolism and the consequences of creatine depletion in muscle. Mol Cell Biochem 133-134:51-66

Young JF, Larsen LB, Malmendal A, Nielsen NC, Straadt IK, Oksbjerg N, Bertram HC (2010) Creatine-induced activation of antioxidative defence in myotube cultures revealed by explorative NMR-based metabonomics and proteomics. J Int Soc Sports Nutr 7:9 
Yquel RJ, Arsac LM, Thiaudiere E, Canioni P, Manier G (2002) Effect of creatine supplementation on phosphocreatine resynthesis, inorganic phosphate accumulation and $\mathrm{pH}$ during intermittent maximal exercise. J Sports Sci 20:427-437

Zemtsov A (2007) Skin phosphocreatine. Skin Res Technol 13:115-118
Zhivotovsky B, Galluzzi L, Kepp O, Kroemer G (2009) Adenine nucleotide translocase: a component of the phylogenetically conserved cell death machinery. Cell Death Differ 16:1419-1425

Ziegenfuss TN, Lowery LM, Lemon PWR (1998) Acute fluid volume changes in men during three days of creatine supplementation. J Exerc Physiol 1:1-9 